\title{
Thermobarometric Constraints on the Depth of Exposure and Conditions of Plutonism and Metamorphism at Deep Levels of the Sierra Nevada Batholith, Tehachapi Mountains, California
}

\author{
DAVID A. PickeTt ${ }^{1}$ AND Jason B. SALEeBy \\ Division of Geological and Planetary Sciences, California Institute of Technology, Pasadena
}

\begin{abstract}
We present thermodynamic estimates of pressures, temperatures, and volatile activities in variably deformed, gabbroic to granitic, Cretaceous (115-100 Ma) batholithic and framework rocks of the Tehachapi Mountains, southernmost Sierra Nevada, California. Al contents of homblende in granitoids imply igneous emplacement at $\sim 8 \mathrm{kbar}$ in the southernmost Tehachapi Mountains, with lower pressures (3$7 \mathrm{kbar}$ ) to the north. Metamorphic pressures and temperatures for garnet-bearing paragneisses and metaigneous rocks were estimated on the basis of garnet-hornblende-plagioclase-quartz and garnet-biotiteplagioclase-quartz thermobarometers. Disparate results for the metaigneous rocks from the latter system point to the difficulty of applying pelite-based thermobarometers to rocks of contrasting composition and mineralogy. Preferred pressures cluster at 7.1-9.4 and 3.6-4.3 kbar. Incomplete knowledge of reaction histories, however, limits our interpretation of the lower pressures because they are minimum estimates. The 4-kbar samples are all from a small area and, if our interpretation is correct, they imply a local, more shallow event superimposed on crust once residing at deeper structural levels. Garnet-homblende and garnet-biotite temperatures are less coherent, likely owing to retrograde $\mathrm{Fe}-\mathrm{Mg}$ exchange, and range from $570^{\circ}$ to $790^{\circ} \mathrm{C}$. The majority of the rocks are igneous and affected by recrystallization and metamorphism during subsolidus cooling; they are not granulites. Country rock paragneisses are typically migmatized at "peak" metamorphic conditions near that of the wet granite solidus $\left(\geq 690^{\circ} \mathrm{C}\right)$. Veinlike paragenesis of garnet in the metaigneous rocks suggests formation related to the presence of a fluid phase. Thermodynamic estimates of volatile activities in these garnet-bearing assemblages suggest variable, mostly $\mathrm{CO}_{2}$-rich fluid compositions, in the absence of any pervasive fluid flux. The igneous rocks of the Tehachapi Mountains were thus intruded at depths of $\sim 30 \mathrm{~km}$, making them the deepest known exposed components of the Cretaceous Sierra Nevada batholith. Metamorphism occurred at these great depths and, perhaps, locally after $\sim 15 \mathrm{~km}$ of uplift before $\sim 87 \mathrm{Ma}$, implying an uplift rate of $1.2 \mathrm{~mm} / \mathrm{yr}$. (A minimum uplift rate is $0.6 \mathrm{~mm} / \mathrm{yr}$.) This original uplift and possible subsequent uplift events may have been related to underthrusting of a block of Rand Schist from what is now the southeast, with concomitant widespread ductile deformation. The deduced pressure-temperature and uplift history is similar to those of highpressure/high-temperature Cretaceous batholithic rocks in Salinia and the San Gabriel Mountains, but direct correlation is not warranted. When compared with higher-level intrusive rocks from analogous portions of the Sierra Nevada batholith to the north, the Tehachapi rocks reveal a deep batholith that is more heterogeneous and somewhat more mafic on average, but displaying a similar level of isotopic hybridization involving mantle and crustal sources. The batholith is quartz-rich at these levels, suggestive of a weak, ductile middle crust susceptible to prolonged deformation and possible delamination.
\end{abstract}

\section{INTRODUCTION}

The Sierra Nevada batholith is a well-studied example of the Phanerozoic plutonic belts common to continental margins. Until recently, however, information about the properties of the belt in the depth dimension was available only indirectly through regional geologic [Hamilton and Myers, 1967] and geophysical [Bateman and Eaton, 1967; Pakiser and Brune, 1980; Saleeby et al., 1986] considerations. Newer studies are beginning to show that the southern exposures of the batholith provide us a view into its deeper structure. In this study, we determine estimated physical conditions attendant on Cretaceous age intrusion and metamorphism in the southernmost portion of the batholith (Tehachapi Mountains), with the chief goal of testing a high-pressure origin. The rocks studied prove to be the deepest yet known from the Sierra Nevada, and their compositional, mineralogical, and structural

\footnotetext{
${ }^{1}$ Now at Isotope Sciences, Los Alamos National Laboratory, Los Alamos, New Mexico.
}

Copyright 1993 by the American Geophysical Union.

Paper number 92JB01889.

0148-0227/93/92JB-01889\$05.00 features have implications for, the description of the geophysical and petrologic nature of deep batholithic crust.

The Tehachapi Mountains lie at the southern end of the Sierra Nevada range in central California (Figures 1 and 2). South and west of the Cretaceous tonalite of Bear Valley Springs, the crystalline basement of the range is composed of gneisses representing Cretaceous calcalkaline intrusive rocks and their metamorphic country rocks [Ross, 1985, 1989; Saleeby et al., 1987; Sams and Saleeby, 1988]. Previous studies [Sharry, 1981; Sams and Saleeby, 1988] have presented data suggestive of high-pressure conditions during the thermal maximum, and Saleeby [1990] has incorporated these observations into a model of the southern half of the Sierra Nevada batholith as an oblique section through the Cretaceous magmatic arc (a model supported by the regional-scale igneous barometric data of Ague and Brimhall [1988b]). The crystalline rocks of the Tehachapi Mountains represent the culmination of this southward deepening; in fact, Ross [1985] has referred to the Tehachapi basement as a "batholithic root." Here we present new field, petrographic, and thermobarometric data that not only lend more substantial support to the high-pressure model for the Tehachapi crystalline rocks but also reveal an apparently complex metamorphic and tectonic history. This scenario may help shed light on the larger-scale tectonic 


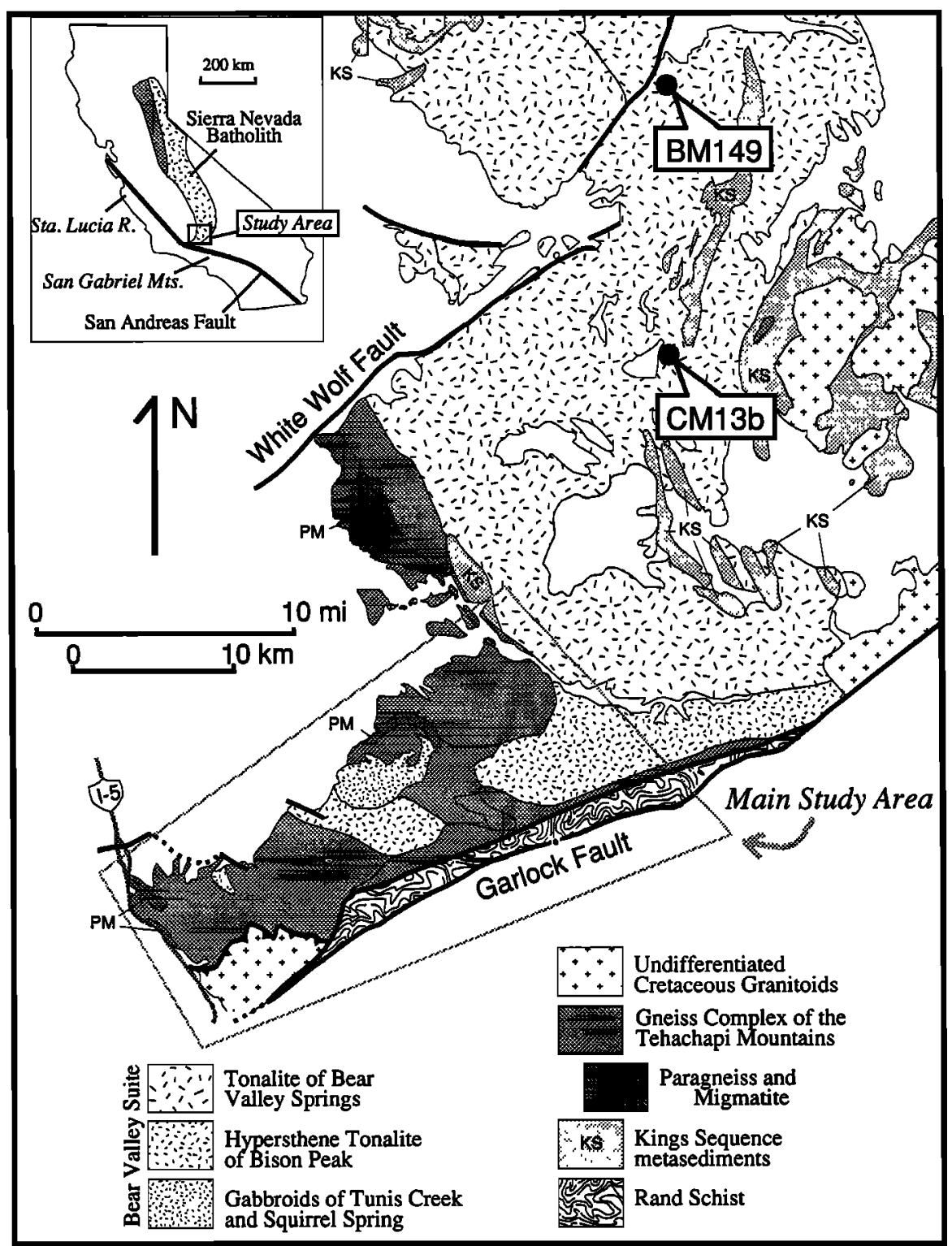

Fig. 1. Basement geologic map of the southern Sierra Nevada with sample localities in the northern study area. Modified after Ross [1989], Sams [1986], and Sharry [1981]. Sample localities are from Sams [1986].

history of the Sierra Nevada and southern California, particularly with respect to those mechanisms responsible for the uplift of such deep rocks.

\section{GEOLOGIC SETTING}

The Tehachapi Mountains are underlain by variably foliated gabbroic to granitic rocks which have intruded chiefly psammitic and calcareous metasedimentary assemblages (Figure 2). These basement rocks are overlain by Tertiary sedimentary and volcanic strata, the lowest belonging to the Eocene Tejon Formation [Nilsen, 1987]. These strata have been affected by relatively recent folds and high-angle faults [Goodman and Malin, 1992; also P. E. Malin et al., "Crustal-scale tilting and exposure of the deep Sierra Nevada batholith, Tehachapi Mountains, California," submitted to the Journal of Geophysical Research, 1992 (hereinafter referred to as P. E. Malin, unpublished manuscript, 1992)], and the rocks of the study area have apparently undergone $\sim 60^{\circ}$ of clockwise rotation since Cretaceous time [Kanter and McWilliams, 1982; McWilliams and $L i, 1985]$, with at least $30^{\circ}$ of that occurring during Miocene time [Plescia and Calderone, 1986]. The crystalline rocks of the Tehachapi range, as considered in this study, are bounded on the southeast by the Pastoria thrust [Crowell, 1964] and the north branch of the Garlock fault, which separate them from a sliver of Rand Schist as well as other Cretaceous igneous and metamorphic rocks [Ross, 1989, and references therein]. Constraints on the timing of uplift of the range are provided by mineral $\mathrm{K}$-Ar ages of $80-87 \mathrm{Ma}$ (summarized by Ross [1989]) and by the Eocene ( 50 Ma) surface exposure of the basement rocks as indicated by the oldest ages at the base of the unconformably overlying strata [Nilsen, 1987].

Whereas Sharry [1981] referred to the basement rocks as products of granulite facies metamorphism, Saleeby et al. [1987] and Sams and Saleeby [1988] used U-Pb zircon data and regional geologic mapping to demonstrate a Cretaceous intrusive age for the basement, and they argued for an igneous origin for most of the pyroxene-bearing "granulitic" assemblages. We feel it is misleading to refer to the Tehachapi crystalline rocks as constituting a granulite terrane since, with 


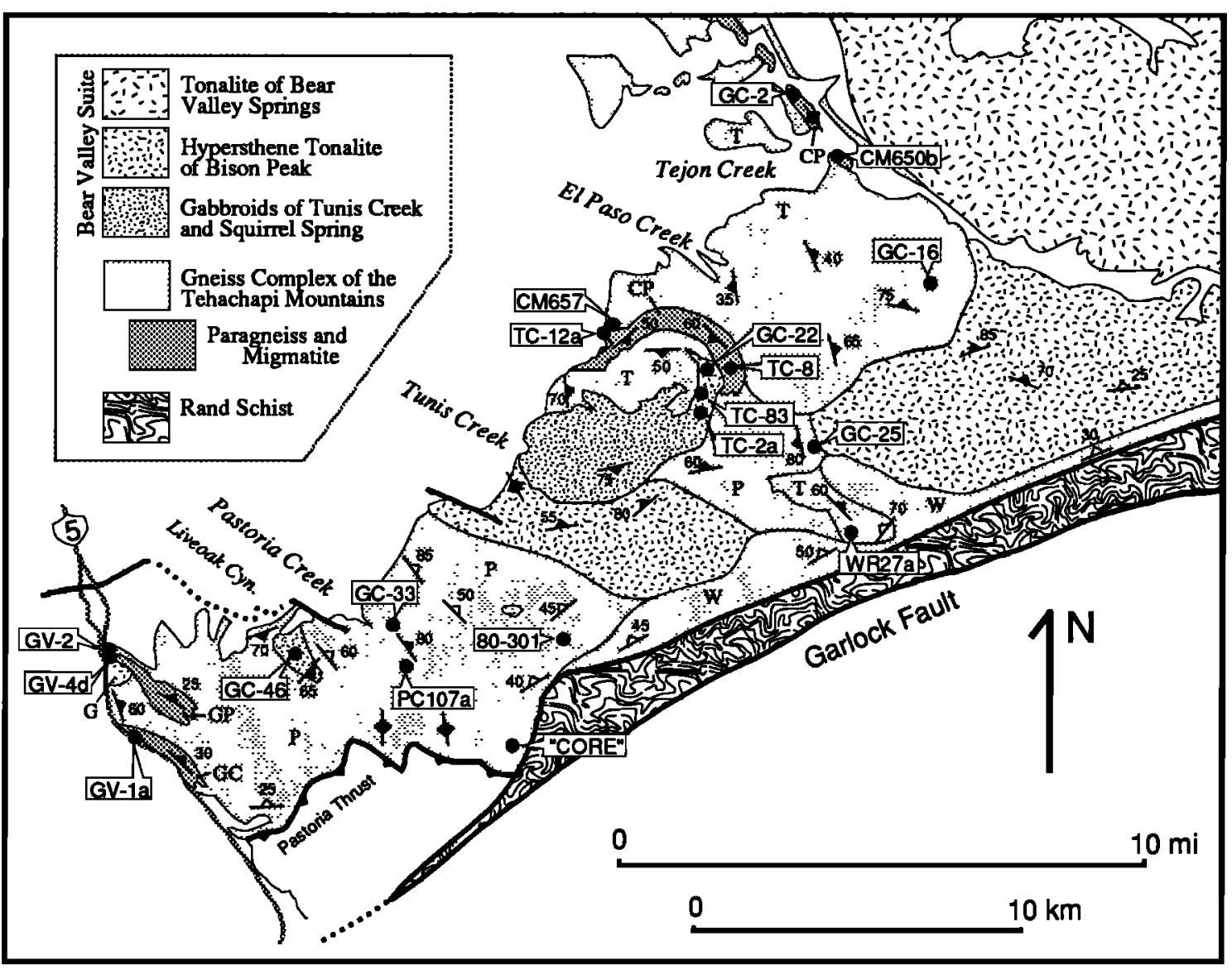

Fig. 2. Basement geologic map of the main study area, Tehachapi Mountains, with sample localities. Modified after Sharry [1981] and Sams [1986], supplemented by new mapping (1:24000 scale) concentrated in the area between Tunis and El Paso Creeks and along Interstate 5. Sample localities for CM650b, CM657, and WR27a from Sams [1986], and for 80-301 and "CORE" from J. Sharry (personal communication, 1990). Units of the gneiss complex of the Tehachapi Mountains: tonalite gneiss of Tejon Creek (T), quartzofeldspathic gneiss of Pastoria Creek (P), diorite gneiss of White Oak (W), paragneiss of Comanche Point (CP), migmatite of Grapevine Peak (GP), and paragneiss of Grapevine Canyon (GC). Unit G is the garnetbiotite tonalite of Grapevine (of the intrusive suite of Bear Valley). Smaller, submap-scale paragneiss bodies are not shown. Solid foliation symbols are magmatic or high-temperature metamorphic fabrics; open foliation symbols are lowertemperature ductile deformation fabrics. For clarity, map patterns are omitted for the Kings Sequence body in the north and the granitic rocks south of the Pastoria thrust (Figure 1)

a few isolated exceptions [Sams and Saleeby, 1988; Ross, 1989], they do not possess prograde granulite facies assemblages. It is also not accurate to refer to the Tehachapi basement as a "mafic gneissic complex" [Ross, 1985], since the predominant lithology is tonalite.

The Tehachapi crystalline rocks are weakly to strongly gneissic, showing effects of both high- and low-temperature deformation. They were divided by Saleeby et al. [1987] into two suites: the gneiss complex of the Tehachapi Mountains and the intrusive suite of Bear Valley (Figures 1 and 2). The lithologically diverse Tehachapi gneiss complex contains three orthogneiss units: the $\sim 115 \mathrm{Ma}$ Tejon Creek tonalite gneiss, the $\sim 115$ Ma Pastoria Creek quartzofeldspathic gneiss, and the White Oak diorite gneiss; as well as three paragneiss units: the Comanche Point paragneiss and the newly recognized Grapevine Canyon paragneiss and Grapevine Peak migmatite (see below). The orthogneisses of the Tehachapi gneiss complex consist mainly of biotite and/or hornblende tonalites grading to biotite granites, with small-scale lithologic heterogeneities, including common dioritic layers. The igneous rocks of the generally less-deformed intrusive suite of Bear Valley ( 100 Ma) are assigned to four units. The biotiteand/or hornblende-bearing tonalite of Bear Valley Springs constitutes a major batholith-scale pluton (Figure 1) which extends from the northern part of the main study area more than $60 \mathrm{~km}$ to the vicinity of Lake Isabella. It grades on the south into the Bison Peak hypersthene tonalite. Also included in the Bear Valley suite are the gabbroids of Tunis Creek and Squirrel Spring (norite to hornblende gabbro, commonly recrystallized and/or metamorphosed) and the newly recognized garnet-biotite tonalite of Grapevine. Separate reports (in preparation) will discuss the igneous petrology and isotopic characteristics of these suites.

The metasedimentary framework rocks consist of high-grade equivalents of quartz-rich clastic and calcareous, continental margin-type assemblages with subordinate metavolcanic rocks. To the north (Figure 1), these are termed Kings Sequence, after Saleeby et al. [1978], and are correlated with pendants exposed throughout the southern Sierra Nevada. Ross [1989] refers to these as "the metasedimentary rocks of Keene." The highergrade, more gneissic metasedimentary rocks of the main part of the study area (the Comanche Point and Grapevine Canyon paragneisses) are not termed Kings Sequence, but they are compositionally similar. These rocks occur at many scales, from mappable, kilometer-scale bodies to outcrop size enclaves. They are always structurally concordant with the 


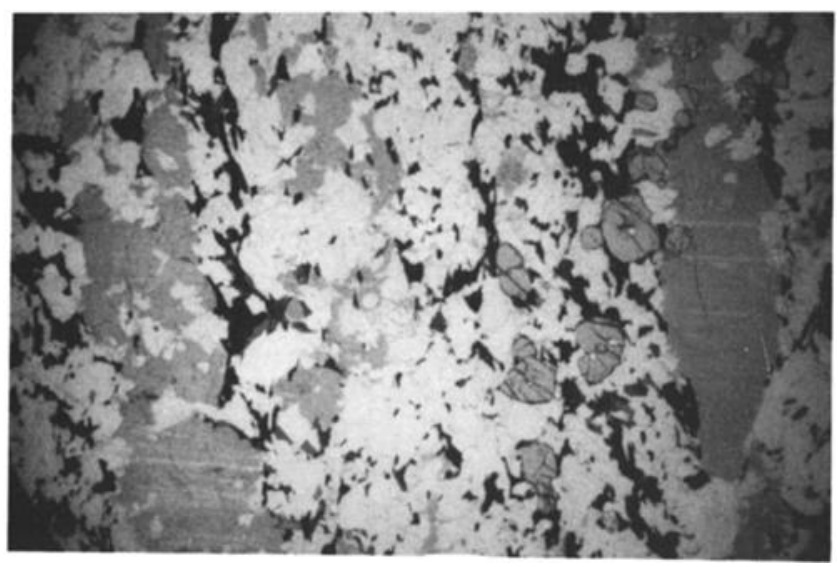

Fig. 3. Photomicrograph ( $9 \mathrm{~mm}$ across) of typical high-grade granoblastic fabric in paragneiss TC-8, consisting of quartz, plagioclase, alkali feldspar (stained), biotite, garnet, and graphite.

intrusive rocks, show no discernible metamorphic gradient near intrusive contacts, and quartzofeldspathic varieties are commonly migmatitic. The migmatite of Grapevine Peak is a major, mappable belt of migmatitic paragneiss showing apparent effects of both partial melting and injection. The metasedimentary rocks of this report are restricted to the Tehachapi gneiss complex suite; the Kings sequence rocks are not discussed.

Deformation fabrics are pervasive in the study area (see also Sharry [1981], Sams [1986], Saleeby et al. [1987], and Sams and Saleeby [1988]). These range from high-temperature, synplutonic (including igneous flow and cumulate layering) and synmetamorphic foliations (Figure 3) to protomylonitic fabrics (e.g., augen gneiss) to solid-state mylonite in discrete domains. The mylonitic fabrics are best developed in quartzrich varieties and formed at intermediate temperatures (usually above chlorite stability) except near the north branch of the Garlock fault. Although local variations in structural pattern are common (notably around the Tunis Creek gabbroid), the regional structural pattern is as follows: the higher temperature fabrics (metamorphic and protoclastic) tend to strike from north to west with moderate to steep dips to the northeast, while protomylonitic to mylonitic fabrics near the north branch of the Garlock fault strike northeast with shallow to moderate dips to the northwest (Figure 2). Transitional zones between the two patterns are evident, such as along the Aqueduct Access Road east of Pastoria Creek. Mylonitic fabrics are also locally well developed to the north in the Bear Valley Springs tonalite [Sams, 1986; Ross, 1989].

\section{METAMORPHIC ASSEMBLAGES}

\section{Quartzofeldspathic Metasedimentary Rocks}

These rocks are generally quartz-rich with subordinate pelitic component. Ross [1989] and Sams and Saleeby [1988] report sillimanite in Kings sequence exposures north of Tejon Creek, but south of here, there is but one recognized occurrence of an $\mathrm{Al}_{2} \mathrm{SiO}_{5}$ phase (discussed below). The predominant assemblage is quartz + plagioclase + alkali feldspar + biotite + graphite, with the common addition of garnet. Muscovite is a common retrograde phase, although some occurrences of larger, subhedral grains may belong to the peak assemblage. Although direct textural evidence for the garnet-forming

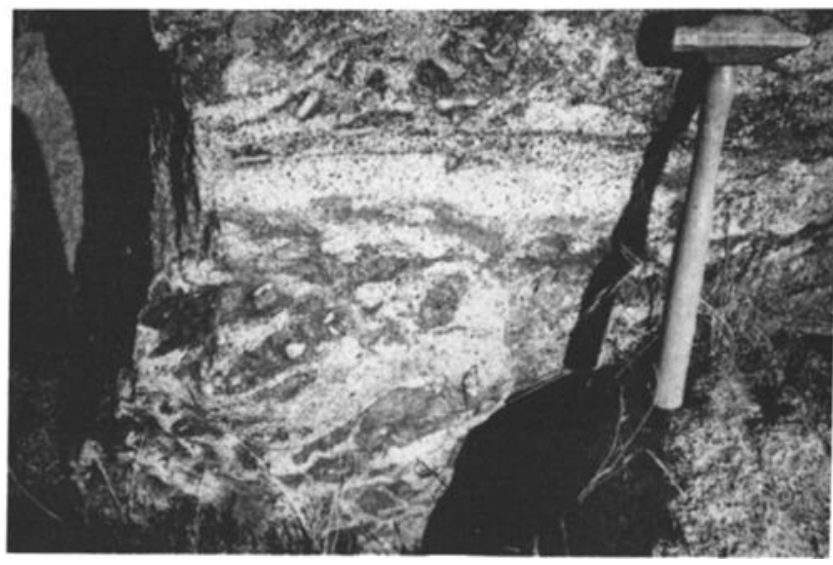

Fig. 4. Field photograph of migmatite of Grapevine Peak (sample locality GV-4d) with biotite \pm garnet melanosomes, quartz + twofeldspar leucosomes, and injection veins of biotite tonalite. Note white, rectangular pseudomorphs (best expressed at the top of the photo), after kyanite, composed chiefly of muscovite. Hammer head is $12.5 \mathrm{~cm}$ long.

reactions is lacking, the tendencies for biotite to be concentrated in alkali feldspar-rich layers and/or around garnet suggest reactions such as

muscovite + biotite +3 quartz $\rightarrow$

2 orthoclase +2 garnet $+2 \mathrm{H}_{2} \mathrm{O}$.

Sams [1986] and Ross [1989] report a few examples of hypersthene-bearing gneisses which appear to have a sedimentary protolith based on, for example, high 18O/160 ratios; however, amphibolite facies assemblages predominate. Metasedimentary textures are gneissic with well-developed migmatitic layers of irregular-width quartz-feldspar leucosomes and biotite-rich melanosomes, suggestive of the production of an incompletely mobilized partial melt. This texture is most profoundly expressed in the migmatite of Grapevine Peak (Figure 2), where in biotite \pm muscovite melanosomes are found lath-shaped aggregates of white mica which have the appearance of retrograde pseudomorphs after an $\mathrm{Al}_{2} \mathrm{SiO}_{5}$ phase (Figure 4). Microscopic examination revealed no evidence for the identity of the original phase, but an $\mathrm{X}$ ray diffraction pattern from a heavy mineral separate of an aggregate (from location GV-4d on Figure 2) yielded a characteristic kyanite X ray pattern, with no indication of sillimanite or andalusite. This is the first reported occurrence of kyanite from any location in the Sierra Nevada batholith.

\section{Calc-Silicate Rocks}

Calcareous metasedimentary rocks in the Comanche Point paragneiss range from almost pure marble (calcite-graphite) to more siliceous compositions. Calc-silicate gneisses have the assemblages quartz + plagioclase + diopside + sphene plus either alkali feldspar + hornblende or garnet + scapolite. An exception is a sample from an enclave on the north slope of Winters Ridge (GC-25 on Figure 2), which contains quartz + diopside + scapolite + wollastonite + calcite + sphene, with latestage symplectic intergrowths of garnet \pm quartz mantling scapolite. Such relations have been reported by Warren et al. [1987] from the granulite terrane of the Arunta Block of central Australia. They attribute the symplectic reaction texture to a lowering of $\mathrm{CO}_{2}$ activity by a local influx of $\mathrm{H}_{2} \mathrm{O}$-rich fluids. 

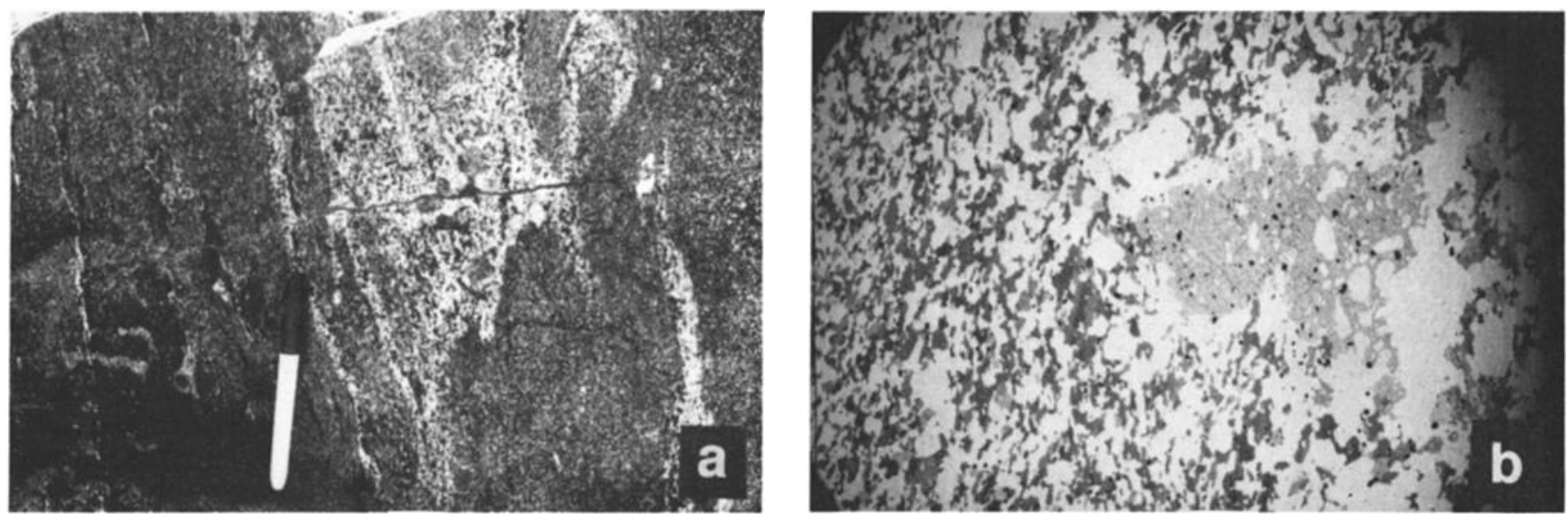

Fig. 5. (a) Field photograph of garnet paragenesis in metagabbro. Matrix rock is hornblende + plagioclase + ilmenite \pm hypersthene. Note two garnet textural settings: as coarse porphyroblasts with felsic haloes in coarser, leucocratic gabbro layers; and as smaller grains along brittle fracture cutting earlier fabric across the center of the photo. There are no significant mineral compositional contrasts between the two settings. Pen is $14 \mathrm{~cm}$ long. (b) Photomicrograph (24 mm across) of metagabbro TC-83, showing halo of plagioclase and quartz around the inclusion-riddled garnet. Mafic minerals are hornblende (with some patchy cummingtonite exsolution) and ilmenite.

\section{Metaigneous Rocks}

The most distinctive characteristic of subsolidus crystallization in the intrusive rocks is the growth of red garnet porphyroblasts (see Ross [1989] for observed localities). Garnet occurrence is widespread but not pervasive; it is most commonly distributed in discrete zones, particularly near contacts with metasedimentary enclaves or other intrusive bodies. In the hornblende \pm hypersthene gabbros of Tunis Creek and Squirrel Spring (Figure 2), the garnet is present as a subsolidus, typically inclusion-filled (plagioclase, quartz, ilmenite) phase in three mesoscopic settings (Figure 5a): (1) in coarse, felsic layers, (2) in discordant veins, and (3) dispersed randomly (less common). In all cases, the garnets are rarely in contact with, and appear to have grown at the expense of, hornblende, resulting in felsic haloes (Figure $5 b$ ) typically containing quartz, which otherwise is absent in the primary assemblage. These relations qualitatively suggest a reaction of the type:

hornblende + plagioclase $\rightarrow$

garnet + plagioclase + quartz $+\mathrm{H}_{2} \mathrm{O}$.

Larger gamets typically have highly irregular forms with some euhedral faces (Figure $5 b$ ). These forms are interpreted to be features of growth rather than resorption because of the lack of Fe-Mg phases that would be resorption products. A subsolidus origin for garnet is supported by its presence in discordant veins and haloes (Figure 5) and by discordance between individual garnet grains and synmagmatic foliation in the host gabbro. Garnet was never found in apparent textural equilibrium with hypersthene. Zones of garnet growth in the Tunis Creek unit are concentrated in a tongue of well-foliated, commonly recrystallized gabbro in the northeast sector of the unit. Another general garnet occurrence in mafic rocks is in diorites along contacts with more felsic intrusive rocks in heterogeneous zones of the Tehachapi gneiss complex suite.

Garnet is also found in tonalite bodies, particularly in biotite tonalites of the gneiss complex of the Tehachapi Mountains. Textural evidence is ambiguous as to whether the garnet is magmatic or subsolidus, owing chiefly to the disturbance of igneous textures by plastic deformation. Nevertheless, the garnet typically shows apparent equilibrium textures with all the primary tonalite phases (biotite, quartz, plagioclase, hornblende), with no segregations or haloes as in the gabbros. In some tonalites, such as the garnet-biotite tonalite of Grapevine (sample GV-2), the garnet is distributed evenly throughout the rock, consistent with a possible magmatic origin. In others (e.g., PC-107a), the garnet is more localized and defines crude veins, consistent with a subsolidus origin. Rarely, in the Pastoria Creek unit, large garnet porphyroblasts occur with felsic haloes in hornblende-rich tonalites.

Cummingtonite is present in many gabbroic rocks, after hypersthene and in reaction relation with hornblende. In some gabbros, hypersthene is replaced by rims of cummingtonite, which are in turn rimmed by hornblende. Cummingtonite also occurs in patchy exsolution zones in hornblende. Another interesting subsolidus assemblage occurs in troctolite of a gabbroic plug in the Pastoria Creek quartzofeldspathic gneiss. Here primary calcic plagioclase and olivine have reacted to produce coronas of orthopyroxene and symplectic hornblende and green spinel. Other minor phases present include chromiterich spinel (picotite), Fe-rich amphibole, and corundum.

Epidote is a common subsolidus phase in the tonalites and granites, found intergrown with biotite in elongate, biotiterich aggregates. The epidote is commonly large and subhedral, with euhedral crystal faces against biotite, and allanite cores are locally observed. However, it cannot be clearly demonstrated in thin section that epidote and biotite were in equilibrium with a melt phase (counter to arguments by Sams [1986]). Lowertemperature, postdeformational alteration has produced white mica and chlorite throughout the study area.

\section{ANALYTICAL PROCEDURES}

Mineral compositions in garnet-bearing assemblages (Tables 1-4) were measured because of their potential for providing pressure and temperature information. Samples exhibiting retrograde alteration of garnet were avoided. Also measured was hornblende in tonalites and granodiorites for igneous pressure determination. Sample localities are depicted on Figures 1 and 2. Samples BM149, WR27a, CM13b, CM657, and CM650b were culled from David Sams' thesis 
collection at Caltech, and sample "CORE" was obtained from John Sharry.

Polished rock thin sections were carbon-coated and analyzed on a JEOL 733 electron microprobe fitted with five wavelength spectrometers. The accelerating voltage was $15 \mathrm{keV}$, the probe current was $25 \mathrm{nA}$ (measured on brass), count time was $60 \mathrm{~s}$, and the probe diameter was $10 \mu \mathrm{m}$. Element standards were wellcharacterized silicates and oxides, and the data were corrected using the "CITZAF" correction program [Armstrong, 1988]. In an attempt to measure equilibrium compositions in coexisting phases, rim analyses were emphasized. From each of three different sites on a section where the requisite phases were in mutual contact, at least three rim spots were analyzed for each phase; the $10 \mu \mathrm{m}$-diameter rim spots were usually centered about $10 \mu \mathrm{m}$ from the rim. Compositions were averaged for each site, and the site means were averaged for the entire thin section to yield the results reported in Tables 1-4. Core spots were also measured for most samples, with the means usually involving 2-3 spots from 2-3 different grains. A few grain traverses were also performed.

Hornblende composition recalculation schemes are described below. For garnet and biotite, all $\mathrm{Fe}$ was assumed to be $\mathrm{Fe}^{2+}$, except for garnet in CM650b. Considering the evidence for relatively reducing conditions in the area, including the presence of phases such as graphite and ilmenite and the paucity of magnetite, this assumption likely results in negligible error.

\section{Garnet}

\section{MineRAL COMPOSITIONS}

Gamets in all occurrences (with the exception of calc-silicate $\mathrm{CM} 650 \mathrm{~b}$ ) are almandine-rich and rather uniform in composition, with $\mathrm{X}_{a l}=0.58-0.73$ (Table 1). Garnets from metagabbros tend to higher pyrope contents $\left(X_{p y}=0.17-0.25\right)$ than those in metatonalites and paragneisses (mostly 0.06 0.18). Paragneiss grossular components are generally lower, and spessartine components are generally higher, than in both metaigneous types. $\mathrm{Fe} /(\mathrm{Fe}+\mathrm{Mg})$ ratios are lower in metagabbros $(0.71-0.79)$ than in metatonalites $(0.81-0.90)$, with the paragneisses spanning a large range. Five previously published [Schürmann, 1938; Ross, 1989] and four unpublished (C. Gallup, personal communication, 1989) gamet analyses from metaigneous rocks in the area fall within these compositional limits.

Zoning is apparent in most garnets in the form of higher $\mathrm{Fe} /(\mathrm{Fe}+\mathrm{Mg}$ ) near the rims with fairly uniform interiors; this is independent of the sizes of the garnets, which range from 0.12 to $1.7 \mathrm{~mm}$, with most less than $1 \mathrm{~mm}$. (For the large, centimeter-scale, irregular, poikiloblastic garnets found in the metagabbros, such as in Figure $5 b$, "core" measurements are from local interiors rather than the core regions of the entire grain; compositions are similar to cores of small garnets in the same thin section.) Table $1 b$ and Figure 6 illustrate garnetzoning profiles. For both garnets in PC107a (Figure 6) and garnet 1 in $\mathrm{TC}-8$, it can be seen that appreciable change in $\mathrm{Fe} /(\mathrm{Fe}+\mathrm{Mg})$ is restricted to the outer $<75 \mu \mathrm{m}$ of the grain for garnets with diameters of 300,900 , and $1100 \mu \mathrm{m}$. Relative uniformity of interiors is also supported by little variation in compositions measured at different core points within other garnets. It is likely that any original growth zoning in these garnets has been obliterated by diffusion, considering the generally small dimensions and high temperatures attained (see below) in light of models of garnet diffusion behavior [e.g., Florence and Spear, 1991]. We interpret the higher $\mathrm{Fe} /(\mathrm{Fe}+\mathrm{Mg})$ near the rims to result from reequilibration between garnet and hornblende or biotite on cooling ("type c" zoning of Selverstone and Chamberlain [1990]). Grossular component is typically not significantly zoned, with three exceptions ("CORE", GV-2, and GV-4d). Spessartine content, when zoned, is higher at the rims in biotite-bearing assemblages but lower at the rims in biotite-free metagabbros; this may be related to stronger partitioning of $\mathrm{Mn}$ into hornblende as suggested by generally higher $\mathrm{MnO}$ contents in hornblende than in biotite (Tables 2 and 3).

\section{Hornblende}

Homblende compositions (Table 2) are recalculated [Spear and Kimball, 1984] by different criteria depending on how the data are to be used. For those used in pressure-temperature (P-T) calculations by the method of Kohn and Spear [1990], the option giving minimum $\mathrm{Fe}^{3+}$ is used. For other applications, the "average $\mathrm{Fe}^{3+"}$ option is used.

Hornblendes in the metaigneous rocks are all quite aluminous, with $\mathrm{Al}^{\mathrm{T}}=2.08-3.36$, a characteristic shared with those in unmetamorphosed intrusive rocks (see below). In the two metatonalites, the hornblendes range in classification [Leake, 1978] from ferro-alumino-tschermakite to ferroan pargasite, with most qualifying as the latter. The ratio $\mathrm{Fe}^{2+} /\left(\mathrm{Fe}^{2+}+\mathrm{Mg}\right)$ ranges from $0.64-0.71$, with the cores either the same or somewhat lower. Hornblendes in metagabbros lie compositionally near the boundaries between tschermakitic, magnesio-, and edenitic homblendes. $\mathrm{Fe}^{2+} /\left(\mathrm{Fe}^{2++\mathrm{Mg})}\right.$ ratios and $K$ contents are lower than in the metatonalite hornblendes, reflective of primary igneous compositional differences. With one exception (TC-2a), both $\mathrm{Fe}^{2+} /\left(\mathrm{Fe}^{2+}+\mathrm{Mg}\right.$ ) and $\mathrm{Al}^{\mathrm{T}}$ are lower in the cores than in the rims. Among both metaigneous types, substantial differences in homblende compositions within one slide were observed, dependent on the adjacent phases; however, these variations are largely nonsystematic. One notable contrast is in $\mathrm{Fe}^{2+} /\left(\mathrm{Fe}^{2+}+\mathrm{Mg}\right)$ of hornblende adjacent to garnet as compared to matrix hornblende: this ratio is higher adjacent to garnet in three samples (PC107a, "CORE", and GC46) but lower in two (TC-2a and TC-83 from the Tunis Creek metagabbro). These differences are likely preserved because of the lack of mesoscale equilibrium during the metamorphic garnet-forming event; igneous hornblende compositions are probably retained away from the garnets.

Hornblende compositions were also measured in unmetamorphosed tonalites and granodiorites which contained assemblages appropriate for $\mathrm{Al}$-in-hornblende igneous barometry. These compositions range from magnesiohomblende in sample BM149 in the north (Figure 1) to ferroan pargasite in the main study area (Figure 2). $\mathrm{Al}^{\mathrm{T}}$ in these hornblendes is generally high, although not as high as in the metaigneous rocks.

\section{Biotite}

The biotites have a fairly wide range of compositions (Table 3), with $\mathrm{Fe} /(\mathrm{Fe}+\mathrm{Mg}$ ) ranging from 0.43 to 0.69 and $\mathrm{Ti}$ from 0.14 to 0.39 atoms per 22 oxygens. There is considerable overlap in compositional parameters between metatonalites and metasediments, so that gross lithologic differences do not alone account for the biotite variability. Zoning, where present, is quite limited in the biotites. 


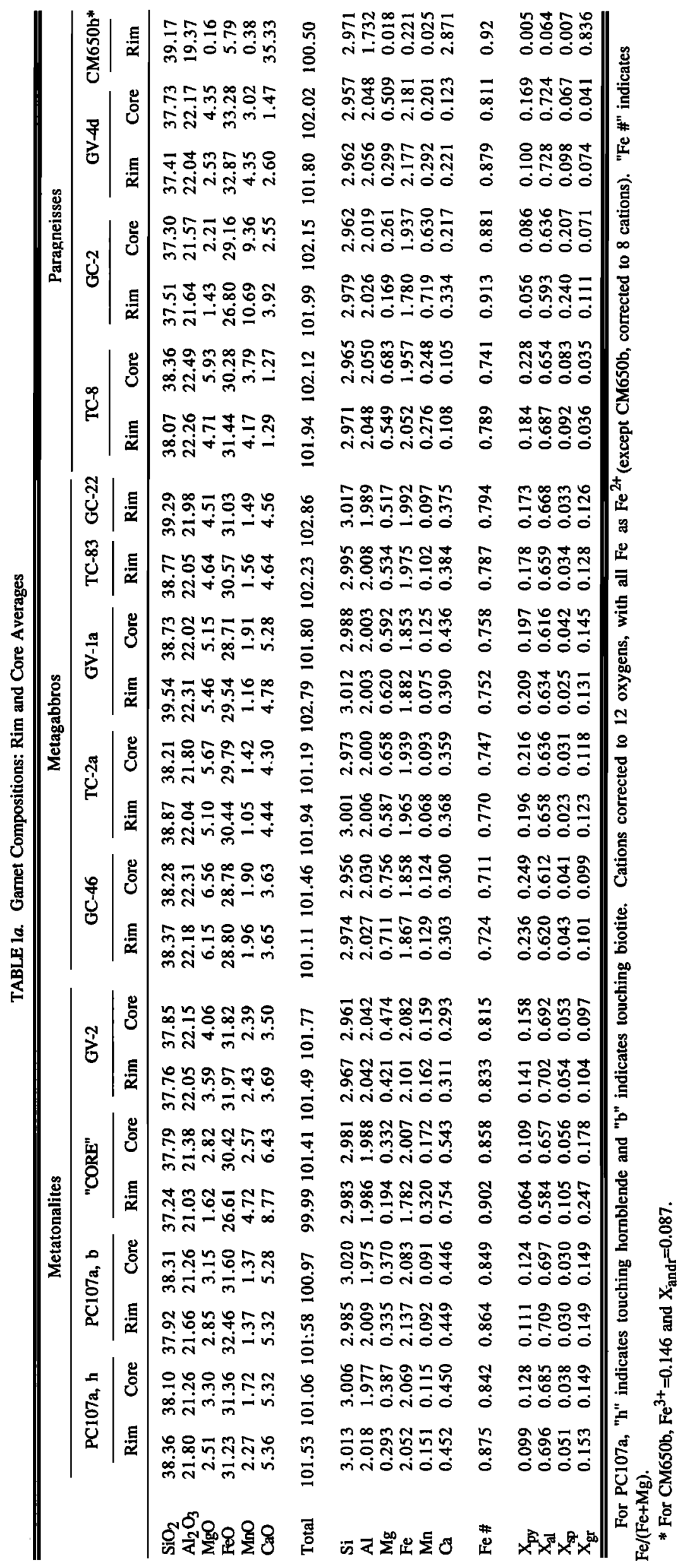




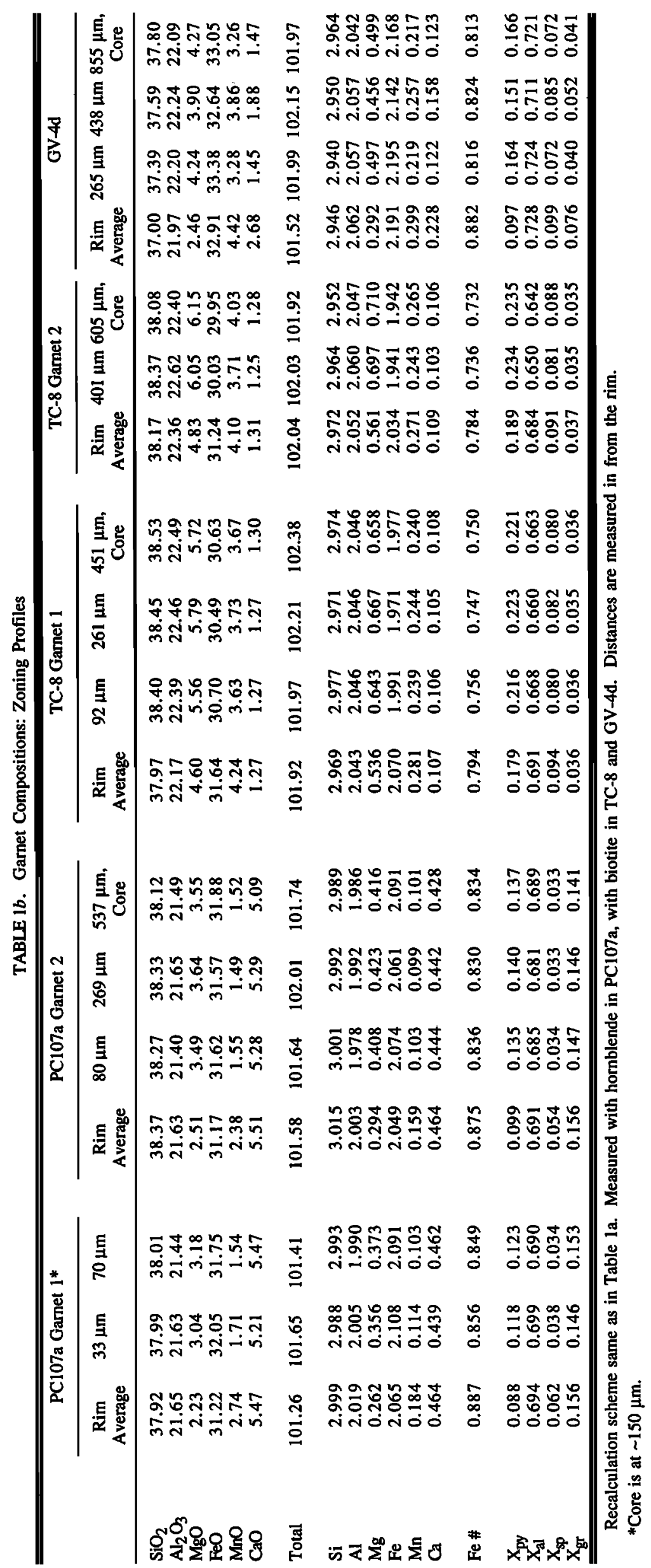




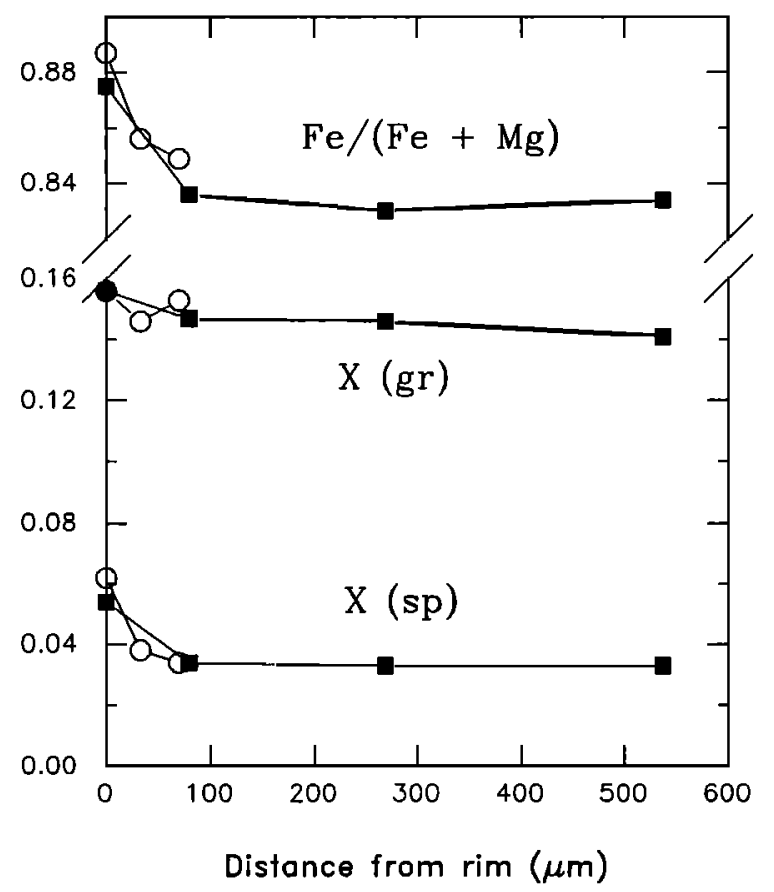

Fig. 6. Zoning profiles of two garnets from metatonalite PC107a. The core of garnet 1 (circles) is at $150 \mu \mathrm{m}$, and the core of gamet 2 (squares) is at $540 \mu \mathrm{m}$.

\section{Plagioclase}

In the paragneisses and metatonalites, plagioclase anorthite contents (Table 4) are relatively low, in the range $A n_{22.38}$, while in the metagabbros, they span $\mathrm{An}_{33-74}$. The two easternmost metagabbros, GC-46 (Liveoak Canyon) and GV-1a (Grapevine Canyon), have An contents that are markedly lower than those from the Tunis Creek metagabbro. In metaigneous rocks, plagioclase measured away from garnet most likely reflects primary igneous compositions. It is notable that throughout the study area igneous plagioclase commonly displays patchy "smoothing" of oscillatory zoning patterns, indicative of limited, near- or subsolidus, internal reequilibration.

Zoning is preserved in metaigneous plagioclase but not in the paragneisses. In metaigneous samples for which cores were measured, all but one (GV-2) have cores more calcic than rims, with the contrast being more marked among the metagabbros. This effect is probably mainly due to inheritance from igneous conditions, with growth of adjacent garnet affecting only the rims of relict igneous grains.

\section{Others}

In the calc-silicate CM650b (with the assemblage quartz + plagioclase + diopside + scapolite + grossular + sphene), a scapolite grain has $\mathrm{X}_{\mathrm{Ca}}=0.74$. Sphenes from this rock are quite aluminous, with $\mathrm{Al}{ }^{\mathrm{vi}}=\mathbf{0 . 6 3}$ per formula unit, while the clinopyroxene has $\mathrm{Mg} /(\mathrm{Mg}+\mathrm{Fe})=0.66$. Alkali feldspar in paragneiss TC-8 was measured in order to help constrain fluid compositions (see below), yielding Or88. Opaque oxide compositions were determined for a limited number of samples; ilmenite was ubiquitous in metamorphosed and unmetamorphosed gabbros to tonalites. Magnetite was present in only a few tonalites, subordinate to ilmenite. On this basis, the intrusive rocks would be termed "ilmenite series."

\section{Pressures, TEMPERATURES, AND FluId CONDITIONS OF INTRUSION AND METAMORPHISM}

\section{Temperature}

Obviously, the majority of rocks in the study area, being igneous in origin, have experienced magmatic temperatures $\left(\sim 675^{\circ} \mathrm{C}\right.$ and above). The main intent of our thermobarometric work here is not to determine such "peak" temperatures but rather to determine depths of emplacement and metamorphism. There is evidence, post-100 Ma open-system U-Pb effects in zircons [Saleeby et al., 1987] and $\sim 86 \mathrm{Ma}$ biotite K/Ar ages [Ross, 1989], for prolonged high temperatures in the area. Therefore it is not clear that even the framework metamorphic rocks will record peak conditions. For these reasons and heeding the reservations of Selverstone and Chamberlain [1990] concerning the validity of core-matrix pressuretemperature determinations, we here emphasize rim mineral compositions in apparent equilibrium settings. Another reason for mistrusting core-matrix calculations in these rocks is the textural and mineral chemical evidence, discussed above, for retention of igneous compositions away from garnet in metaigneous rocks. A potential problem with the rim-rim approach is the likelihood that diffusional homogenization at the high temperatures and generally small length scales of garnet involved here will obscure information on the early history. Furthermore, continued Fe-Mg exchange on cooling (Figure 6) will likely affect temperature calculations, while garnet $\mathrm{Ca}$ contents will respond more slowly, if at all, to the cooling path, obscuring pressure information. Nevertheless, inspection of the estimations by Selverstone and Chamberlain [1990] and simulations by Florence and Spear [1991] of erroneous P-T paths suggests that, in most cases, rim compositions should provide approximate minimum pressure estimates, particularly since garnet homogenization will obscure the highest grossular contents achieved.

Garnet-hornblende. Temperatures based on Fe-Mg exchange between garnet and hornblende [Graham and Powell, 1984] were applied to five metagabbros and two gamet-bearing tonalites (Table 5). The three samples from the Tunis Creek metagabbro gave very similar temperatures of $580^{\circ}-590^{\circ} \mathrm{C}$, while the other two metagabbros, GC-46 from Liveoak Canyon $\left(760^{\circ}\right)$ and GV1a from Grapevine Canyon $\left(700^{\circ}\right)$, record significantly higher temperatures. This difference is substantiated by the aforementioned observation that $\mathrm{Fe}^{2+} /\left(\mathrm{Fe}^{2+}+\mathrm{Mg}\right)$ in hornblende is lower adjacent to gamet than in the matrix for the Tunis Creek samples (TC-2a and TC-83) but not elsewhere. That is, Tunis Creek homblendes have exchanged more extensively with garnet because they equilibrated at lower temperatures. Garnet core-matrix hornblende temperatures are also shown in Table 5, but these are not considered reliable indicators of early conditions because of possible diffusion effects (see above) and the possibility that localized garnet growth precluded any equilibrium with matrix hornblende. If the matrix hornblendes had been in equilibrium with garnet early on, the abundance of homblende would buffer it against effects of diffusion out of garnet, meaning that the core-matrix temperatures would be minima for early conditions.

Two tonalites (PC107a and "CORE") from the Pastoria Creek quartzofeldspathic gneiss unit give garnet-hornblende temperatures $\left(690^{\circ}-700^{\circ}\right)$ similar to those in non-Tunis Creek metagabbros. These are lower than tonalite solidus temperatures and suggest a mechanism for garnet growth similar to that in the gabbros. 
TABLE 2. Hornblende Compositions

\begin{tabular}{|c|c|c|c|c|c|c|c|c|c|c|c|c|c|}
\hline & \multicolumn{7}{|c|}{ Metatonalites } & \multicolumn{6}{|c|}{ Metagabbros } \\
\hline & \multicolumn{2}{|c|}{ PC107a } & \multirow{2}{*}{$\frac{\mathrm{PC} 107 \mathrm{a}, \mathrm{p}}{\operatorname{Rim}}$} & \multicolumn{2}{|c|}{ "CORE" } & \multicolumn{2}{|c|}{ "CORE", p } & \multicolumn{2}{|c|}{ GC-46 } & \multicolumn{2}{|c|}{ GC-46, p } & \multicolumn{2}{|c|}{ TC-2a } \\
\hline & Rim & Core & & Rim & Core & Rim & Core & Rim & Core & $\operatorname{Rim}$ & Core & Rim & Core \\
\hline $\mathrm{SiO}_{2}$ & 40.42 & 40.69 & 41.01 & 40.60 & 40.44 & 40.32 & 39.99 & 41.91 & 43.50 & 41.69 & 43.63 & 44.73 & 43.98 \\
\hline $\mathrm{Al}_{2} \mathrm{O}_{3}$ & 16.63 & 15.45 & 15.59 & 15.47 & 14.71 & 15.74 & 15.21 & 16.76 & 14.21 & 15.71 & 14.28 & 11.99 & 12.30 \\
\hline $\mathrm{TiO}_{2}$ & 0.13 & 0.24 & 0.66 & 0.75 & 0.96 & 0.66 & 0.87 & 0.19 & 0.78 & 0.53 & 0.79 & 1.28 & 1.03 \\
\hline $\mathrm{MgO}$ & 4.84 & 5.72 & 6.01 & 5.41 & 5.47 & 5.39 & 5.56 & 7.36 & 10.53 & 9.38 & 10.42 & 11.01 & 10.39 \\
\hline $\mathrm{FeO}^{*}$ & 21.20 & 21.46 & 20.84 & 21.37 & 22.19 & 21.71 & 22.17 & 17.27 & 15.12 & 16.00 & 16.03 & 16.40 & 18.31 \\
\hline $\mathrm{MnO}$ & 0.24 & 0.26 & 0.19 & 0.32 & 0.31 & 0.32 & 0.30 & 0.26 & 0.25 & 0.25 & 0.25 & 0.10 & 0.18 \\
\hline $\mathrm{CaO}$ & 11.24 & 11.21 & 11.62 & 11.42 & 11.41 & 11.41 & 11.50 & 11.45 & 10.60 & 10.67 & 10.17 & 10.59 & 9.85 \\
\hline $\mathrm{Na}_{2} \mathrm{O}$ & 1.37 & 1.83 & 1.57 & 1.59 & 1.59 & 1.62 & 1.55 & 1.53 & 1.81 & 2.04 & 1.82 & -1.72 & 1.57 \\
\hline $\mathrm{K}_{2} \mathrm{O}$ & 0.90 & 0.77 & 0.88 & 0.98 & 1.12 & 1.03 & 1.24 & 0.29 & 0.23 & 0.22 & 0.23 & 0.40 & 0.27 \\
\hline Total & 96.98 & 97.64 & 98.36 & 97.90 & 98.20 & 98.20 & 98.39 & 97.02 & 97.02 & 96.49 & 97.62 & 98.22 & 97.89 \\
\hline $\mathrm{Si}$ & 6.216 & 6.238 & 6.194 & 6.214 & 6.209 & 6.136 & 6.096 & 6.287 & 6.451 & 6.205 & 6.366 & 6.592 & 6.547 \\
\hline $\mathrm{Al}^{\mathrm{iv}}$ & 1.784 & 1.762 & 1.806 & 1.786 & 1.791 & 1.864 & 1.904 & 1.713 & 1.550 & 1.795 & 1.634 & 1.408 & 1.453 \\
\hline $\mathrm{Al}^{\mathrm{vi}}$ & 1.231 & 1.030 & 0.969 & 1.004 & 0.872 & 0.961 & 0.829 & 1.251 & 0.934 & 0.961 & 0.823 & 0.675 & 0.706 \\
\hline$A l^{T}$ & 3.015 & 2.792 & 2.775 & 2.790 & 2.663 & 2.825 & 2.733 & 2.964 & 2.484 & 2.756 & 2.457 & 2.083 & 2.159 \\
\hline $\mathbf{T i}$ & 0.016 & 0.028 & 0.075 & 0.086 & 0.111 & 0.075 & 0.100 & 0.022 & 0.087 & 0.059 & 0.087 & 0.142 & 0.116 \\
\hline $\mathrm{Mg}$ & 1.110 & 1.307 & 1.354 & 1.233 & 1.250 & 1.222 & 1.263 & 1.646 & 2.326 & 2.079 & 2.266 & 2.418 & 2.305 \\
\hline $\mathrm{Fe}^{3+}$ & & & 0.192 & & 0.005 & 0.224 & 0.307 & & & 0.435 & 0.575 & & 0.011 \\
\hline $\mathrm{Fe}^{2+}$ & 2.726 & 2.751 & 2.440 & 2.736 & 2.844 & 2.540 & 2.519 & 2.166 & 1.875 & 1.557 & 1.381 & 2.021 & 2.269 \\
\hline $\mathrm{Mn}$ & 0.032 & 0.034 & 0.024 & 0.042 & 0.040 & 0.041 & 0.039 & 0.033 & 0.031 & 0.031 & 0.031 & 0.012 & 0.023 \\
\hline $\mathrm{Ca}$ & 1.853 & 1.841 & 1.880 & 1.872 & 1.877 & 1.861 & 1.878 & 1.841 & 1.686 & 1.702 & 1.590 & 1.672 & 1.571 \\
\hline $\mathrm{Na}^{\mathrm{M}}$ & 0.032 & 0.009 & 0.066 & 0.026 & 0.000 & 0.076 & 0.065 & 0.041 & 0.061 & 0.175 & 0.247 & 0.059 & 0.000 \\
\hline $\mathrm{Na}^{\mathrm{A}}$ & 0.377 & 0.534 & 0.393 & 0.445 & 0.472 & 0.403 & 0.393 & 0.403 & 0.460 & 0.413 & 0.267 & 0.433 & 0.453 \\
\hline $\mathbf{K}$ & 0.177 & 0.151 & 0.169 & 0.191 & 0.219 & 0.200 & 0.241 & 0.056 & 0.044 & 0.043 & 0.043 & 0.075 & 0.052 \\
\hline $\mathrm{Fe}^{2+} /\left(\mathrm{Fe}^{2+}+\mathrm{Mg}\right)$ & 0.711 & 0.678 & 0.643 & 0.689 & 0.695 & 0.675 & 0.666 & 0.568 & 0.447 & 0.428 & 0.379 & 0.455 & 0.496 \\
\hline
\end{tabular}

\begin{tabular}{|c|c|c|c|c|c|c|c|c|c|c|c|c|c|}
\hline & \multicolumn{6}{|c|}{ Metagabbros } & \multicolumn{7}{|c|}{ Unmetamorphosed Tonalites and Granodiorites } \\
\hline & \multirow{2}{*}{$\frac{\text { TC-2a, p }}{\operatorname{Rim}}$} & \multicolumn{2}{|c|}{ GV-1a } & \multirow{2}{*}{$\frac{\mathrm{TC}-83}{\operatorname{Rim}}$} & \multirow{2}{*}{$\frac{\text { TC-83, p }}{\operatorname{Rim}}$} & \multirow{2}{*}{$\frac{\mathrm{GC}-22}{\operatorname{Rim}}$} & \multirow{2}{*}{$\frac{\text { BM149 }}{\operatorname{Rim}}$} & \multirow{2}{*}{$\frac{\mathrm{CM} 13 \mathrm{~b}}{\operatorname{Rim}}$} & \multirow{2}{*}{$\begin{array}{l}\text { WR27a } \\
\text { Rim }\end{array}$} & \multirow{2}{*}{$\frac{\text { TC-12a }}{\operatorname{Rim}}$} & \multirow{2}{*}{$\frac{\mathrm{GC}-16}{\operatorname{Rim}}$} & \multirow{2}{*}{$\frac{\mathrm{CM} 657}{\operatorname{Rim}}$} & \multirow{2}{*}{$\frac{\text { GC-33 }}{\text { Rim }}$} \\
\hline & & Rim & Core & & & & & & & & & & \\
\hline $\mathrm{SiO}_{2}$ & 43.51 & 43.02 & 44.88 & 44.44 & 44.09 & 44.30 & 47.13 & 42.56 & 42.74 & 42.14 & 40.93 & 39.74 & 39.69 \\
\hline $\mathrm{Al}_{2} \mathrm{O}_{3}$ & 14.66 & 17.71 & 14.30 & 12.34 & 13.38 & 12.64 & 8.05 & 11.48 & 12.80 & 12.31 & 12.63 & 13.06 & 13.74 \\
\hline $\mathrm{TiO}_{2}$ & 0.92 & 0.36 & 0.74 & 1.47 & 0.98 & 1.29 & 0.73 & 0.70 & 1.38 & 0.88 & 0.43 & 1.13 & 1.41 \\
\hline $\mathrm{MgO}$ & 8.89 & 8.34 & 10.64 & 10.73 & 8.79 & 10.13 & 10.89 & 5.45 & 8.96 & 7.26 & 6.06 & 5.10 & 5.70 \\
\hline $\mathrm{FeO}^{*}$ & 18.24 & 15.58 & 14.64 & 16.52 & 19.44 & 17.05 & 17.31 & 24.07 & 17.33 & 19.71 & 21.89 & 23.18 & 22.42 \\
\hline $\mathrm{MnO}$ & 0.16 & 0.13 & 0.12 & 0.14 & 0.30 & 0.12 & 0.41 & 0.56 & 0.43 & 0.43 & 0.91 & 0.61 & 0.54 \\
\hline $\mathrm{CaO}$ & 10.09 & 11.48 & 11.16 & 10.93 & 10.01 & 10.97 & 12.05 & 11.48 & 11.78 & 11.58 & 10.96 & 11.26 & 11.42 \\
\hline $\mathrm{N}_{2} \mathrm{O}$ & 1.91 & 1.55 & 1.55 & 1.74 & 1.81 & 1.47 & 0.89 & 1.43 & 1.42 & 1.53 & 1.75 & 1.63 & 1.38 \\
\hline $\mathrm{K}_{2} \mathrm{O}$ & 0.52 & 0.41 & 0.26 & 0.50 & 0.44 & 0.58 & 0.74 & 1.48 & 1.60 & 1.44 & 1.58 & 1.83 & 1.93 \\
\hline Total & 98.90 & 98.58 & 98.27 & 98.81 & 99.24 & 98.55 & 98.20 & 99.21 & 98.44 & 97.28 & 97.14 & 97.54 & 98.23 \\
\hline $\mathbf{S i}$ & 6.346 & 6.281 & 6.534 & 6.529 & 6.432 & 6.536 & 6.967 & 6.508 & 6.394 & 6.457 & 6.351 & 6.211 & 6.119 \\
\hline $\mathrm{Al}^{\mathrm{iv}}$ & 1.654 & 1.719 & 1.466 & 1.471 & 1.568 & 1.464 & 1.033 & 1.492 & 1.606 & 1.543 & 1.649 & 1.789 & 1.881 \\
\hline $\mathrm{Al}_{\mathrm{T}}^{\mathrm{vi}}$ & 0.866 & 1.329 & 0.988 & 0.666 & 0.734 & 0.734 & 0.370 & 0.577 & 0.651 & 0.681 & 0.661 & 0.618 & 0.616 \\
\hline $\mathrm{Al}^{\mathrm{T}}$ & 2.520 & 3.048 & 2.454 & 2.137 & 2.302 & 2.198 & 1.403 & 2.069 & 2.257 & 2.224 & 2.310 & 2.407 & 2.497 \\
\hline $\mathrm{Ti}$ & 0.101 & 0.040 & 0.080 & 0.162 & 0.108 & 0.143 & 0.081 & 0.080 & 0.155 & 0.101 & 0.050 & 0.133 & 0.164 \\
\hline $\mathbf{M g}$ & 1.932 & 1.815 & 2.308 & 2.349 & 1.911 & 2.227 & 2.399 & 1.242 & 1.998 & 1.658 & 1.401 & 1.188 & 1.311 \\
\hline $\mathrm{Fe}^{3+}$ & 0.509 & & & & 0.572 & & 0.203 & 0.178 & 0.096 & 0.077 & 0.258 & 0.175 & 0.266 \\
\hline $\mathrm{Fe}^{2+}$ & 1.716 & 1.902 & 1.782 & 2.030 & 1.800 & 2.104 & 1.937 & 2.900 & 2.072 & 2.449 & 2.583 & 2.855 & 2.625 \\
\hline $\mathrm{Mn}$ & 0.020 & 0.016 & 0.014 & 0.017 & 0.037 & 0.015 & 0.051 & 0.073 & 0.054 & 0.056 & 0.120 & 0.081 & 0.070 \\
\hline & 1.577 & 1.796 & 1.741 & 1.721 & 1.565 & 1.734 & 1.909 & 1.881 & 1.888 & 1.901 & 1.822 & 1.886 & 1.887 \\
\hline $\mathrm{Na}^{\mathrm{M} 4}$ & 0.279 & 0.102 & 0.086 & 0.055 & 0.274 & 0.043 & 0.049 & 0.069 & 0.085 & 0.077 & 0.105 & 0.065 & 0.061 \\
\hline $\mathrm{Na}^{\mathrm{A}}$ & 0.261 & 0.337 & 0.353 & 0.441 & 0.238 & 0.378 & 0.206 & 0.355 & 0.327 & 0.378 & 0.422 & 0.429 & 0.353 \\
\hline $\mathbf{K}$ & 0.097 & 0.076 & 0.049 & 0.094 & 0.082 & 0.109 & 0.140 & 0.289 & 0.305 & 0.282 & 0.313 & 0.365 & 0.379 \\
\hline $\mathrm{Fe}^{2+} /\left(\mathrm{Fe}^{2+}+\mathrm{Mg}\right)$ & 0.470 & 0.512 & 0.436 & 0.464 & 0.485 & 0.486 & 0.447 & 0.700 & 0.509 & 0.596 & 0.648 & 0.706 & 0.667 \\
\hline
\end{tabular}

The letter " $p$ " indicates measured touching plagioclase only. Otherwise, measured touching garnet, plagioclase, and quartz in metamorphosed rocks, and touching quartz in unmetamorphosed rocks. See text for correction procedures. 
TABLE 3. Biotite Compositions

\begin{tabular}{|c|c|c|c|c|c|c|c|c|c|c|c|c|}
\hline & \multicolumn{5}{|c|}{ Metatonalites } & \multicolumn{7}{|c|}{ Paragneisses } \\
\hline & \multicolumn{2}{|c|}{ PC107a } & \multirow{2}{*}{$\frac{\text { "CORE", ng }}{\operatorname{Rim}}$} & \multicolumn{2}{|c|}{ GV-2 } & \multicolumn{2}{|c|}{ TC-8 } & \multirow{2}{*}{$\frac{\text { TC-8, ng }}{\operatorname{Rim}}$} & \multicolumn{2}{|c|}{ GC-2 } & \multicolumn{2}{|c|}{ GV-4d } \\
\hline & $\operatorname{Rim}$ & Core & & Rim & Core & $\operatorname{Rim}$ & Core & & Rim & Core & Rim & Core \\
\hline $\mathrm{SiO}_{2}$ & 34.69 & 35.14 & 36.03 & 36.05 & 35.87 & 36.55 & 36.33 & 36.28 & 36.71 & 36.65 & 35.74 & 35.72 \\
\hline $\mathrm{Al}_{2} \mathrm{O}_{3}$ & 17.32 & 17.83 & 17.51 & 19.82 & 19.29 & 19.44 & 19.39 & 19.56 & 18.58 & 18.58 & 19.14 & 19.25 \\
\hline $\mathrm{TiO}_{2}$ & 2.79 & 2.46 & 2.56 & 1.91 & 2.29 & 2.80 & 2.92 & 3.53 & 1.11 & 1.21 & 1.90 & 1.88 \\
\hline $\mathrm{MgO}$ & 6.55 & 6.08 & 7.49 & 9.59 & 9.93 & 11.66 & 11.68 & 11.08 & 6.71 & 6.69 & 9.81 & 9.81 \\
\hline $\mathrm{FeO}$ & 23.81 & 24.32 & 22.44 & 18.71 & 18.74 & 15.42 & 15.80 & 15.73 & 21.78 & 22.09 & 19.65 & 19.60 \\
\hline $\mathrm{MnO}$ & 0.12 & 0.14 & 0.16 & 0.15 & 0.10 & 0.08 & 0.07 & 0.11 & 0.44 & 0.40 & 0.12 & 0.10 \\
\hline $\mathrm{CaO}$ & 0.09 & 0.03 & 0.02 & 0.03 & 0.00 & 0.12 & 0.01 & 0.01 & 0.07 & 0.06 & 0.00 & 0.00 \\
\hline $\mathrm{Na}_{2} \mathrm{O}$ & 0.07 & 0.14 & 0.10 & 0.12 & 0.21 & 0.10 & 0.09 & 0.08 & 0.05 & 0.04 & 0.21 & 0.25 \\
\hline $\mathrm{K}_{2} \mathrm{O}$ & 8.83 & 9.05 & 9.39 & 9.30 & 9.38 & 9.08 & 9.55 & 9.67 & 8.64 & 8.32 & 9.22 & 9.19 \\
\hline Total & 94.27 & 95.21 & 95.7 & 95.68 & 95.81 & 95.25 & 95.84 & 96.05 & 94.09 & 94.04 & 95.79 & 95.80 \\
\hline $\mathrm{Si}$. & 5.460 & 5.484 & 5.541 & 5.427 & 5.404 & 5.430 & 5.390 & 5.373 & 5.682 & 5.672 & 5.405 & 5.398 \\
\hline $\mathrm{Al}^{\mathrm{iv}}$ & 2.540 & 2.516 & 2.459 & 2.573 & 2.596 & 2.570 & 2.610 & 2.627 & 2.318 & 2.328 & 2.595 & 2.602 \\
\hline $\mathrm{Al}^{\mathrm{vi}}$ & 0.673 & 0.763 & 0.715 & 0.942 & 0.830 & 0.835 & 0.781 & 0.788 & 1.070 & 1.060 & 0.817 & 0.828 \\
\hline $\mathrm{Ti}$ & 0.330 & 0.288 & 0.296 & 0.215 & 0.259 & 0.313 & 0.326 & 0.393 & 0.129 & 0.141 & 0.215 & 0.215 \\
\hline Mg & 1.537 & 1.414 & 1.717 & 2.152 & 2.229 & 2.581 & 2.584 & 2.447 & 1.548 & 1.542 & 2.211 & 2.210 \\
\hline $\mathrm{Fe}$ & 3.135 & 3.177 & 2.886 & 2.356 & 2.361 & 1.917 & 1.960 & 1.948 & 2.818 & 2.859 & 2.485 & 2.478 \\
\hline $\mathbf{M n}$ & 0.016 & 0.018 & 0.021 & 0.018 & 0.013 & 0.010 & 0.008 & 0.014 & 0.058 & 0.052 & 0.016 & 0.013 \\
\hline $\mathrm{Ca}$ & 0.016 & 0.005 & 0.004 & 0.005 & 0.000 & 0.018 & 0.002 & 0.002 & 0.012 & 0.010 & 0.000 & 0.000 \\
\hline $\mathrm{Na}$ & 0.021 & 0.041 & 0.030 & 0.034 & 0.060 & 0.028 & 0.027 & 0.023 & 0.015 & 0.013 & 0.062 & 0.072 \\
\hline $\mathbf{K}$ & 1.772 & 1.801 & 1.843 & 1.787 & 1.802 & 1.722 & 1.808 & 1.828 & 1.706 & 1.642 & 1.779 & 1.771 \\
\hline $\mathrm{Fe} /(\mathrm{Fe}+\mathrm{Mg})$ & 0.671 & 0.692 & 0.627 & 0.523 & 0.514 & 0.426 & 0.431 & 0.443 & 0.645 & 0.650 & 0.529 & 0.529 \\
\hline
\end{tabular}

The letters "ng" indicate not touching garnet. Cations corrected to 22 oxygens with all $\mathrm{Fe}$ as $\mathrm{Fe}^{2+}$.

Garnet-biotite. The difficulty of obtaining reliable garnetbiotite $\mathrm{Fe}-\mathrm{Mg}$ exchange temperatures in high-grade terranes is well established [e.g., Chipera and Perkins, 1988]. A large part of the uncertainty arises from the probability of diffusional modification of $\mathrm{Fe} /(\mathrm{Fe}+\mathrm{Mg})$ patterns in garnet and biotite. We therefore consider most of our calculations to provide rough estimates of minimum temperatures achieved. In Table 6 are temperature estimates using the widely utilized Ferry and Spear [1978] calibration (with modifications by Hodges and Spear [1982]), calculated at pressures discussed below (except GV-4d at $8 \mathrm{kbar}$ ). Included are calculations utilizing data in Sharry [1981] for rim compositions of "CORE" and 80-301. Calculated temperatures cover a wide range of $570^{\circ}-960^{\circ} \mathrm{C}$, with most lying between $630^{\circ}$ and $790^{\circ} \mathrm{C}$. The highest apparent temperatures are from the four metatonalites $\left(738^{\circ}, 957^{\circ}, 716^{\circ}\right.$, and $788^{\circ} \mathrm{C}$ ), leading to the suggestion that the garnets are magmatic in origin. However, textures in "CORE" and PC107a are more suggestive (though not definitive) of subsolidus growth, and all (except, perhaps, the $957^{\circ} \mathrm{C}$ temperature) could be attained in the subsolidus of a dry tonalite. Another possible reason for the high apparent metatonalite temperatures is the difference in whole-rock, garnet (generally higher $\mathrm{X}_{g r}$ and lower $\mathrm{X}_{s p}$ ), and biotite (higher Ti and $\mathrm{Fe} /(\mathrm{Fe}+$ $\mathrm{Mg}$ ), lower $\mathrm{Al}$ ) compositions, as well as mineralogy, compared with the pelitic rocks for which garnet-biotite thermometry was developed. Note that in two samples ("CORE" and PC107a) for which garnet-hornblende temperatures were also determined, the garnet-biotite temperatures are $50^{\circ}$ and $260^{\circ}$ higher, respectively. These high temperatues point to the possible inapplicability of the common garnet-biotite thermometers to intermediate igneous rocks; this is a subject worthy of further study [see Anderson, 1988]. We consider the results for paragneisses TC-8 $\left(630^{\circ} \mathrm{C}\right), \mathrm{GC}-2\left(630^{\circ} \mathrm{C}\right)$, and $\mathrm{GV}-4 \mathrm{~d}\left(570^{\circ} \mathrm{C}\right)$ to be more reliable as minimum estimates.
Assuming that peak conditions had been in the range of $650^{\circ}$ $750^{\circ} \mathrm{C}$, the retention of garnet-biotite closure temperatures of $570^{\circ}-630^{\circ} \mathrm{C}$ recorded in garnet within $20 \mu \mathrm{m}$ of the rim implies rapid cooling. Diffusion calculations by F. Spear [personal communication, 1992] suggest that, under these conditions, cooling rates of at least $500^{\circ} \mathrm{C} / \mathrm{Ma}$ are consistent with the calculated temperatures and garnet profiles.

Plagioclase-scapolite. In the calc-silicate sample CM650b, temperature was calculated using compositions of coexisting plagioclase and scapolite based on the calibration of Goldsmith and Newton [1977], yielding $780^{\circ}$. The sample comes from a relatively thin septum of paragneiss surrounded by tonalite (Figure 2), so it would not be too surprising for a refractory calcsilicate rock to have recorded a high temperature in such a setting.

\section{Pressure}

Sams and Saleeby [1988] summarized the arguments suggestive of high pressure for the plutonic and metamorphic rocks of the Tehachapi Mountains. We would add one caveat to the portion of that discussion concerning magmatic epidote: the lithologies showing possible magmatic epidote do not usually contain all the phases required to constrain pressure to $>6 \mathrm{kbar}$ [Zen, 1989]. Furthermore, the two pressure determinations of Sharry [1981] are based on an assemblage in which the state of equilibrium is suspect (see below). In light of the uncertainties inherent in these previous arguments, we present here an attempt to gain a more quantitative basis for high-pressure claims.

We noted above the presence of relict kyanite in a partially melted paragneiss injected with tonalite (GV-4d; Figures 2 and 4). We interpret kyanite to have been formed during migmatite formation due to its occurrence in biotite-rich melanosomes; an origin by retrogression of sillimanite on cooling seems 
TABLE 4. Plagioclase Compositions

\begin{tabular}{|c|c|c|c|c|c|c|c|c|c|c|c|c|c|c|}
\hline & \multicolumn{10}{|c|}{ Metatonalites } & \multicolumn{4}{|c|}{ Metagabbros } \\
\hline & \multicolumn{2}{|c|}{$\begin{array}{c}\text { PC107a } \\
\text { h }\end{array}$} & \multirow{2}{*}{$\frac{\begin{array}{c}\text { PC107a, } \\
b\end{array}}{\text { Rim }}$} & \multirow{2}{*}{$\begin{array}{c}\begin{array}{c}\text { PC107a, } \\
\text { ng }\end{array} \\
\text { Rim }\end{array}$} & \multicolumn{2}{|c|}{$\begin{array}{c}\text { "CORE", } \\
\text { h }\end{array}$} & \multicolumn{2}{|c|}{$\begin{array}{c}\text { "CORE", } \\
\text { ng }\end{array}$} & \multicolumn{2}{|c|}{$\begin{array}{c}\text { GV-2, } \\
\text { b }\end{array}$} & \multicolumn{2}{|c|}{$\begin{array}{c}\text { GC- } 46, \\
h\end{array}$} & \multicolumn{2}{|c|}{$\begin{array}{c}\text { GC-46, } \\
\text { ng }\end{array}$} \\
\hline & Rim & Core & & & Rim & Core & $\operatorname{Rim}$ & Core & Rim & Core & Rim & Core & Rim & Core \\
\hline $\begin{array}{l}\mathrm{SiO}_{2} \\
\mathrm{Al}_{2} \mathrm{O}_{3} \\
\mathrm{FeO} \\
\mathrm{CaO} \\
\mathrm{Na}_{2} \mathrm{O} \\
\mathrm{K}_{2} \mathrm{O}\end{array}$ & $\begin{array}{r}59.91 \\
25.22 \\
0.10 \\
6.67 \\
8.00 \\
0.07\end{array}$ & $\begin{array}{r}59.23 \\
25.84 \\
0.02 \\
7.43 \\
7.63 \\
0.10\end{array}$ & $\begin{array}{r}60.23 \\
25.71 \\
0.11 \\
6.99 \\
8.35 \\
0.08\end{array}$ & $\begin{array}{r}59.92 \\
25.22 \\
0.18 \\
6.74 \\
7.91 \\
0.20\end{array}$ & $\begin{array}{r}61.99 \\
23.52 \\
0.20 \\
4.84 \\
9.28 \\
0.08\end{array}$ & $\begin{array}{r}61.50 \\
24.06 \\
0.10 \\
5.39 \\
8.94 \\
0.08\end{array}$ & $\begin{array}{r}61.21 \\
24.83 \\
0.21 \\
6.00 \\
8.66 \\
0.08\end{array}$ & $\begin{array}{r}59.55 \\
25.70 \\
0.05 \\
7.19 \\
7.94 \\
0.14\end{array}$ & $\begin{array}{r}58.45 \\
27.01 \\
0.34 \\
8.37 \\
7.52 \\
0.14\end{array}$ & $\begin{array}{r}59.97 \\
26.11 \\
0.05 \\
7.37 \\
8.28 \\
0.07\end{array}$ & $\begin{array}{r}58.71 \\
25.25 \\
0.20 \\
7.10 \\
7.87 \\
0.09\end{array}$ & $\begin{array}{r}55.02 \\
28.27 \\
0.11 \\
10.37 \\
5.99 \\
0.05\end{array}$ & $\begin{array}{r}56.51 \\
27.16 \\
0.11 \\
9.06 \\
6.83 \\
0.06\end{array}$ & $\begin{array}{r}54.72 \\
28.67 \\
0.03 \\
10.61 \\
5.84 \\
0.05\end{array}$ \\
\hline Total & 99.97 & 100.25 & 101.47 & 100.17 & 99.91 & 100.07 & 100.99 & 100.57 & $101.83 \quad 1$ & 101.85 & 99.22 & 99.81 & 99.73 & 99.92 \\
\hline $\begin{array}{l}\mathrm{Si} \\
\mathrm{Al} \\
\mathrm{Fe} \\
\mathrm{Ca} \\
\mathrm{Na} \\
\mathrm{K}\end{array}$ & $\begin{array}{l}2.670 \\
1.326 \\
0.004 \\
0.319 \\
0.692 \\
0.004\end{array}$ & $\begin{array}{l}2.638 \\
1.357 \\
0.001 \\
0.354 \\
0.659 \\
0.006\end{array}$ & $\begin{array}{l}2.652 \\
1.334 \\
0.004 \\
0.330 \\
0.713 \\
0.005\end{array}$ & $\begin{array}{l}2.669 \\
1.324 \\
0.007 \\
0.322 \\
0.683 \\
0.011\end{array}$ & $\begin{array}{l}2.748 \\
1.229 \\
0.007 \\
0.230 \\
0.798 \\
0.005\end{array}$ & $\begin{array}{l}2.731 \\
1.260 \\
0.004 \\
0.257 \\
0.769 \\
0.004\end{array}$ & $\begin{array}{l}2.700 \\
1.291 \\
0.008 \\
0.283 \\
0.740 \\
0.004\end{array}$ & $\begin{array}{l}2.645 \\
1.346 \\
0.002 \\
0.342 \\
0.683 \\
0.008\end{array}$ & $\begin{array}{l}2.579 \\
1.401 \\
0.013 \\
0.395 \\
0.643 \\
0.008\end{array}$ & $\begin{array}{l}2.634 \\
1.352 \\
0.002 \\
0.347 \\
0.705 \\
0.004\end{array}$ & $\begin{array}{l}2.641 \\
1.339 \\
0.007 \\
0.342 \\
0.687 \\
0.005\end{array}$ & $\begin{array}{l}2.486 \\
1.505 \\
0.004 \\
0.502 \\
0.525 \\
0.003\end{array}$ & $\begin{array}{l}2.547 \\
1.442 \\
0.004 \\
0.438 \\
0.597 \\
0.004\end{array}$ & $\begin{array}{l}2.470 \\
1.525 \\
0.001 \\
0.513 \\
0.511 \\
0.003\end{array}$ \\
\hline \multirow[t]{4}{*}{$\begin{array}{l}X(a n) \\
X(a b)\end{array}$} & $\begin{array}{l}0.314 \\
0.682\end{array}$ & $\begin{array}{l}0.347 \\
0.647\end{array}$ & $\begin{array}{l}0.315 \\
0.680\end{array}$ & $\begin{array}{l}0.317 \\
0.672\end{array}$ & $\begin{array}{l}0.223 \\
0.773\end{array}$ & $\begin{array}{l}0.250 \\
0.747\end{array}$ & $\begin{array}{l}0.276 \\
0.721\end{array}$ & $\begin{array}{l}0.331 \\
0.661\end{array}$ & $\begin{array}{l}0.378 \\
0.615\end{array}$ & $\begin{array}{l}0.329 \\
0.668\end{array}$ & $\begin{array}{l}0.331 \\
0.664\end{array}$ & $\begin{array}{l}0.487 \\
0.510\end{array}$ & $\begin{array}{l}0.422 \\
0.575\end{array}$ & $\begin{array}{l}0.500 \\
0.498\end{array}$ \\
\hline & \multicolumn{8}{|c|}{ Metagabbros } & \multicolumn{6}{|c|}{ Paragneisses } \\
\hline & \multicolumn{2}{|c|}{$\begin{array}{c}\text { TC-2a, } \\
\text { h }\end{array}$} & $\begin{array}{c}\text { TC-2a, } \\
\text { ng }\end{array}$ & \multicolumn{2}{|c|}{$\begin{array}{c}\text { GV-1a, } \\
\quad h\end{array}$} & $\begin{array}{c}\text { TC-83 } \\
\text { h }\end{array}$ & $\begin{array}{c}\text { TC-83, } \\
\text { ng }\end{array}$ & $\begin{array}{c}\text { GC-22, } \\
h\end{array}$ & \multicolumn{2}{|c|}{$\begin{array}{c}\text { TC-8, } \\
\text { b }\end{array}$} & $\begin{array}{r}\text { TC-8, } \\
\text { ng,b }\end{array}$ & \multicolumn{2}{|c|}{$\begin{array}{c}\mathrm{GC}-2, \\
\mathrm{~b}\end{array}$} & CM650b \\
\hline & $\operatorname{Rim}$ & Core & Rim & Rim & Core & Rim & $\operatorname{Rim}$ & $\operatorname{Rim}$ & $\operatorname{Rim}$ & Core & Rim & Rim & Core & Rim \\
\hline $\begin{array}{l}\mathrm{SiO}_{2} \\
\mathrm{Al}_{2} \mathrm{O}_{3} \\
\mathrm{FeO} \\
\mathrm{CaO} \\
\mathrm{Na}_{2} \mathrm{O} \\
\mathrm{K}_{2} \mathrm{O}\end{array}$ & $\begin{array}{r}51.53 \\
31.64 \\
0.23 \\
13.91 \\
4.35 \\
0.05\end{array}$ & $\begin{array}{r}49.54 \\
32.24 \\
0.08 \\
15.05 \\
3.20 \\
0.04\end{array}$ & $\begin{array}{r}51.77 \\
31.45 \\
0.11 \\
13.71 \\
4.46 \\
0.06\end{array}$ & $\begin{array}{r}59.93 \\
26.51 \\
0.26 \\
7.99 \\
7.38 \\
0.06\end{array}$ & $\begin{array}{r}57.36 \\
27.47 \\
0.01 \\
9.14 \\
6.83 \\
0.07\end{array}$ & $\begin{array}{r}49.58 \\
32.90 \\
0.25 \\
15.31 \\
3.32 \\
0.04\end{array}$ & $\begin{array}{r}52.86 \\
30.95 \\
0.19 \\
13.07 \\
4.94 \\
0.06\end{array}$ & $\begin{array}{r}50.57 \\
32.63 \\
0.17 \\
15.27 \\
2.99 \\
0.04\end{array}$ & $\begin{array}{r}60.67 \\
25.74 \\
0.20 \\
6.79 \\
8.42 \\
0.22\end{array}$ & $\begin{array}{r}60.66 \\
25.59 \\
0.01 \\
6.79 \\
8.38 \\
0.32\end{array}$ & $\begin{array}{r}59.75 \\
25.95 \\
0.01 \\
7.31 \\
7.50 \\
0.32\end{array}$ & $\begin{array}{r}62.40 \\
24.54 \\
0.26 \\
5.47 \\
9.24 \\
0.22\end{array}$ & $\begin{array}{r}62.23 \\
24.48 \\
0.06 \\
5.54 \\
9.18 \\
0.29\end{array}$ & $\begin{array}{r}45.06 \\
35.21 \\
0.00 \\
18.43 \\
1.07 \\
0.04\end{array}$ \\
\hline Total & 101.71 & 100.15 & 101.56 & 102.13 & 100.88 & 101.40 & 102.07 & 101.67 & 102.04 & 101.75 & 100.84 & 102.13 & 101.78 & 99.81 \\
\hline $\begin{array}{l}\mathrm{Si} \\
\mathrm{Al} \\
\mathrm{Fe} \\
\mathrm{Ca} \\
\mathrm{Na} \\
\mathrm{K}\end{array}$ & $\begin{array}{l}2.311 \\
1.673 \\
0.009 \\
0.669 \\
0.379 \\
0.003\end{array}$ & $\begin{array}{l}2.259 \\
1.733 \\
0.003 \\
0.736 \\
0.283 \\
0.003\end{array}$ & $\begin{array}{l}2.323 \\
1.663 \\
0.004 \\
0.659 \\
0.387 \\
0.003\end{array}$ & $\begin{array}{l}2.624 \\
1.368 \\
0.010 \\
0.375 \\
0.626 \\
0.004\end{array}$ & $\begin{array}{l}2.552 \\
1.441 \\
0.000 \\
0.436 \\
0.590 \\
0.004\end{array}$ & $\begin{array}{l}2.238 \\
1.751 \\
0.009 \\
0.741 \\
0.290 \\
0.002\end{array}$ & $\begin{array}{l}2.357 \\
1.627 \\
0.007 \\
0.624 \\
0.427 \\
0.003\end{array}$ & $\begin{array}{l}2.269 \\
1.725 \\
0.008 \\
0.734 \\
0.260 \\
0.002\end{array}$ & $\begin{array}{l}2.657 \\
1.329 \\
0.007 \\
0.319 \\
0.715 \\
0.012\end{array}$ & $\begin{array}{l}2.664 \\
1.325 \\
0.000 \\
0.319 \\
0.714 \\
0.018\end{array}$ & $\begin{array}{l}2.645 \\
1.354 \\
0.001 \\
0.347 \\
0.644 \\
0.018\end{array}$ & $\begin{array}{l}2.721 \\
1.262 \\
0.010 \\
0.256 \\
0.781 \\
0.012\end{array}$ & $\begin{array}{l}2.723 \\
1.262 \\
0.002 \\
0.260 \\
0.779 \\
0.016\end{array}$ & $\begin{array}{l}2.080 \\
1.916 \\
0.000 \\
0.912 \\
0.096 \\
0.002\end{array}$ \\
\hline $\begin{array}{l}X(a n) \\
X(a b)\end{array}$ & $\begin{array}{l}0.637 \\
0.361\end{array}$ & $\begin{array}{l}0.720 \\
0.277\end{array}$ & $\begin{array}{l}0.628 \\
0.369\end{array}$ & $\begin{array}{l}0.373 \\
0.623\end{array}$ & $\begin{array}{l}0.423 \\
0.573\end{array}$ & $\begin{array}{l}0.717 \\
0.281\end{array}$ & $\begin{array}{l}0.592 \\
0.405\end{array}$ & $\begin{array}{l}0.737 \\
0.261\end{array}$ & $\begin{array}{l}0.305 \\
0.684\end{array}$ & $\begin{array}{ll}5 & 0.304 \\
4 & 0.679\end{array}$ & $\begin{array}{l}0.344 \\
0.638\end{array}$ & $\begin{array}{l}0.244 \\
0.745\end{array}$ & $\begin{array}{l}0.246 \\
0.738\end{array}$ & $\begin{array}{l}0.903 \\
0.095\end{array}$ \\
\hline
\end{tabular}

The letter "h" indicates touching hornblende and garnet, except GC-33 with no garnet; "b" indicates touching biotite and garnet; "ng" indicates not touching garnet; "ng,b" indicates not touching garnet or biotite. Cations corrected to 8 oxygens.

unlikely in light of the sluggish kinetics of the reaction. Using the intersection of the fluid-present metapelitemetagraywacke liquidus of Vielzeuf and Holloway [1988] and the kyanite $\rightarrow$ sillimanite curve of Bohlen et al. [1991], these relations indicate a minimum temperature of $690^{\circ} \mathrm{C}$ at a minimum pressure of $7.6 \mathrm{kbar}$. Thus it is clear that metamorphism, probably accompanying intrusion at the thermal maximum, was at both high temperature and pressure. We have combined quantitative geobarometers with the above geothermometers to place better constraints on pressures throughout the study area.

Garnet-hornblende-plagioclase-quartz. Combined with the Graham and Powell [1984] garnet-homblende geothermometer, we have utilized the empirical geobarometer for garnet amphibolites of Kohn and Spear [1990]. The results (Table 5, Figures 7 and 9) place the samples into the same two groupings as did the temperatures. The three samples of the Tunis Creek metagabbro (in the center of the study area), which gave the lower garnet-hornblende temperatures $\left(580^{\circ}-590^{\circ} \mathrm{C}\right)$, yield pressures of $3.6-4.2 \mathrm{kbar}$. The other samples, from the western part of the study area, evidently equilibrated at much higher pressures: 8.2, 7.3, and 7.5 kbar from Pastoria Creek, Liveoak Canyon, and Grapevine Canyon, respectively, and $10.8 \mathrm{kbar}$ for "CORE" (from near the convergence of the Pastoria thrust and the north branch of the Garlock fault). It should be mentioned that the garnet and hornblende $\mathrm{Fe}^{2+} /\left(\mathrm{Fe}^{2+}+\mathrm{Mg}\right)$ ratios in tonalites $\mathrm{PC} 107 \mathrm{a}(8.2 \mathrm{kbar})$ and "CORE" (10.8 kbar) are higher than the recommended range of 


\begin{tabular}{cccccc}
\multicolumn{6}{c}{ TABLE 5. Gamet-Homblende Temperatures* and } \\
Gamet-Homblende-Plagioclase-Quartz Pressures ${ }^{\dagger}$ & \\
\hline & & $T,{ }^{\circ} \mathrm{C}$ & $P$, kbar & $T,{ }^{\circ} \mathrm{C}$ & $P$, kbar \\
Rims & Rims & Core-Matrix Core-Matrix \\
\hline Metagabbros & TC-83 & 578 & 3.8 & & \\
& GC-22 & 586 & 3.6 & & \\
& TC-2a & 588 & 4.2 & 697 & 4.6 \\
& GV-1a & 676 & 7.5 & & \\
& GC-46 & 757 & 7.3 & 678 & 6.1 \\
Metatonalites & "CORE" & 686 & 10.8 & 743 & 9.8 \\
& PC107a & 701 & 8.2 & 707 & 8.3 \\
\hline
\end{tabular}

\footnotetext{
*Graham and Powell [1984].

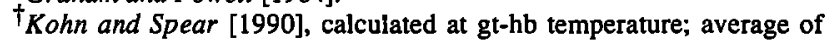
results from $\mathrm{Fe}$ and $\mathrm{Mg}$ end-member reactions.
}

TABLE 6. Garnet-Biotite Temperatures* and Garnet-Biotite-Plagioclase-Quartz Pressures ${ }^{\dagger}$ From Rim Compositions

\begin{tabular}{llcc}
\hline & & $T,{ }^{\circ} \mathrm{C}$ & $P$, kbar \\
\hline Metatonalites & "CORE" & 738 & 12.7 \\
& PC107a & 957 & 17.4 \\
& GV-2 & 716 & 9.4 \\
& $80-301^{\ddagger}$ & 788 & 7.1 \\
Paragneisses & TC-8 & 630 & 4.3 \\
& GC-2 & 626 & 8.7 \\
& GV-4d & 573 & \\
\hline
\end{tabular}

*Ferry and Spear [1978] with modifications by Hodges and Spear [1982].

${ }^{\dagger}$ Average of reactions R1 and R2 of Hoisch [1990], calculated simultaneously with the thermometer.

${ }_{\text {}}$ Calculations are based on data by Sharry [1981]. No biotite touching garnet was found in our thin section of "CORE."

${ }_{\text {At } P}=8 \mathrm{kbar}$.

Kohn and Spear [1990], meaning that their pressures may be somewhat overestimated.

Such a large pressure difference within the study area, among units with no discernible major tectonic boundaries, is somewhat surprising. The low slopes of lines of equal $\ln K_{e q}$ in Figure 7 show that temperature variations cannot be responsible for disparate pressure determinations. One way to evaluate the validity of the high pressures is to calculate pressures based on pairings of mineral compositions (rim, core, or matrix) that would give the lowest possible result (highest-Ca plagioclase and lowest-Ca garnet). Such calculations for the four high-P samples yield 9.0 ("CORE"), 8.0 (PC107a), 6.1 (GV-1a), and 5.0 (GC-46) kbar. Only in the case of GC-46 is this pressure indistinguishable from the low Tunis Creek pressures, and it is based on only one measured point in one plagioclase grain. As mentioned above, cores of plagioclases that display marked zoning (such as GC-46) most likely reflect igneous conditions; this is particularly expected since we have measured them only in the rare spots where hornblende, which is being consumed, survives next to garnet. Therefore we attach little significance to pressures calculated using plagioclase cores or in the matrix. (Such core-matrix pressures are shown in Table 5, and they show no particular pattern: they are within $\pm 1 \mathrm{kbar}$ of rim results.) We thus conclude that the low-pressure/high-pressure dichotomy among the samples, as shown by the rim calculations, is a real effect.

Garnet-biotite-(muscovite)-plagioclase-quartz. Sharry [1981] used a reaction based on this assemblage to calculate temperatures and pressures for samples "CORE" $\left(640^{\circ} \mathrm{C}, 8.5\right.$

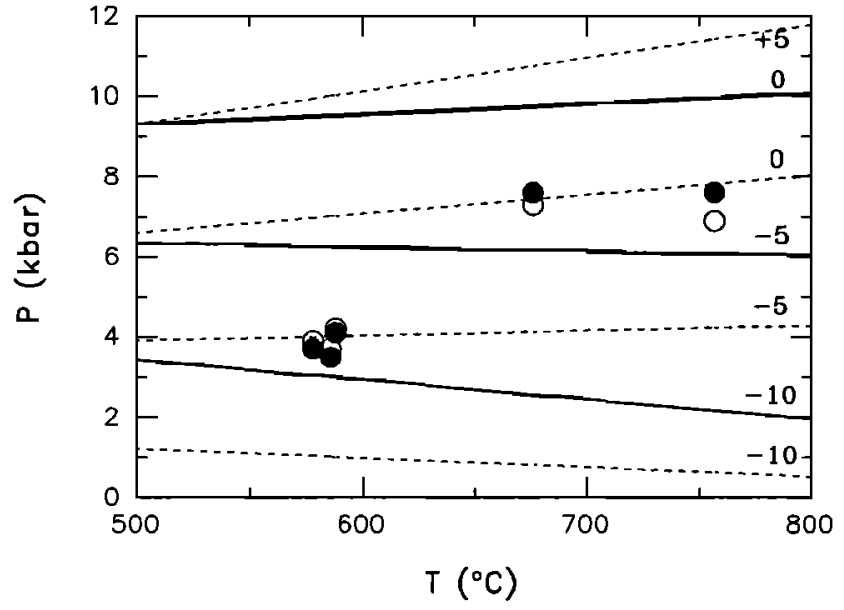

Fig. 7. Results of garnet-hornblende-plagioclase-quartz P-T estimates. Solid circles are from the $\mathrm{Mg}$ reaction, open circles from the $\mathrm{Fe}$ reaction. Solid lines are labeled isopleths of $\ln \mathrm{K}_{\mathrm{eq}}$ for the $\mathrm{Mg}$ reaction, and dashed lines represent the Fe reaction. Estimated relative uncertainties are shown in the upper left.

kbar) and $80-301\left(779^{\circ} \mathrm{C}, 8.1 \mathrm{kbar}\right)$; he did, however, express some doubt that the muscovite in this assemblage is an equilibrium phase. In the present study, as well as in that of Sams [1986], there are no observed samples with strong textural evidence for equilibrium among all these phases. However, Hoisch [1990] has proposed six empirically calibrated geobarometers utilizing such assemblages with or without muscovite. We have applied the two muscovite-free reactions ( $R 1$ and $R 2$ ), combined with the garnet-biotite geothermometer described above, to our samples and the two Sharry [1981] samples (Table 6). Figure 8 shows P-T lines for the barometric and thermometric expressions for two samples; there is a stronger temperature dependence of calculated pressures than for the garnet-hornblende-plagioclase-quartz barometer (Figure 7).

For two samples, PC107a and "CORE", we can compare the garnet-biotite-plagioclase-quartz results to those based on the garnet-hornblende-plagioclase-quartz geobarometer. Pressures from the former reaction (17.4 kbar for PC107a, 12.7 kbar for "CORE") are 9.2 and $1.8 \mathrm{kbar}$ higher than those from the latter. The biotite compositions and equilibrium constants for these two metatonalites lie outside of the recommended ranges for the Hoisch [1990] barometers, and the calculated pressures are well outside of Hoisch's calibration range. We therefore prefer the garnet-hornblende-plagioclase-quartz results for these samples. These discrepancies again point to the potential difficulties of applying to metaigneous rocks thermobarometers developed for pelitic rocks.

Metatonalites GV-2 and 80-301, along with the paragneisses, do lie within (or nearly so) Hoisch's compositional ranges, and we therefore consider their results to be more realistic (although the higher pressures are still on the margins of Hoisch's calibration range). Pressures for these four samples (boxes in Figure 9) range from 4.3 to $9.4 \mathrm{kbar}$, and an interesting areal variation pattern is evident. One of the samples of Comanche Point paragneiss (TC-8) yields the same low pressure ( $\sim 4 \mathrm{kbar})$ as the nearby Tunis Creek metagabbros, whereas the two samples to the southwest (80-301 and GV-2) and the one to the north (GC-2) yield high pressures. Thus there is again a dichotomy, with high-pressure rocks lying on either side of the low-pressure Tunis Creek area. Calculations 
of "lowest possible pressure," as described above for the gamethornblende-plagioclase-quartz barometer, do not yield appreciably lower pressures in any samples.

Al-in-hornblende igneous geobarometer. An effort was made to locate suitable granitoids for estimating pressure from the $\mathrm{Al}$

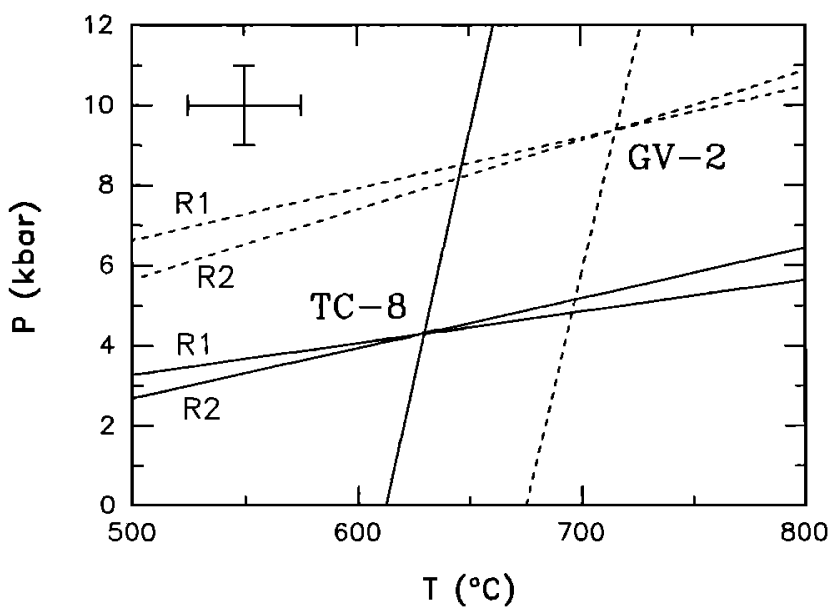

Fig. 8. Results of garnet-biotite-plagioclase-quartz P-T estimates for two representative samples (TC-8: solid lines; GV-2: dashed lines). Steep lines are garnet-biotite thermometric expressions, while shallow lines are simultaneously calculated barometric expressions from reactions R1 and R2 [Hoisch, 1990]. The intersection of the three curves defines the estimated P-T point. Estimated relative uncertainties are shown in the upper left. contents of hornblende [Hammarstrom and Zen, 1986]; we utilized the calibration of Hollister et al. [1987] because it is based on natural assemblages in settings similar to those in this study. Only a few rocks of proper assemblage were found that also lacked extensive deformation and alteration features, and their calculated pressures are shown in Table 7 and Figure 10. Sample BM149, from $45 \mathrm{~km}$ north of the main study area, has the lowest hornblende pressure of $3.2 \mathrm{kbar}$, while CM13b, from near Keene on Tehachapi Creek, yields $6.9 \mathrm{kbar}$. Ague and Brimhall [1988b] report pressures consistent with these on four nearby samples (Figure 10). Five samples from the main study area, from the Tejon Creek and Pastoria Creek gneiss units, give pressures of $7.8-9.3 \mathrm{kbar}$. These values lie in the same range as those for the seven higher-pressure metamorphic samples (Table 7); however, these high igneous pressures are also found near the four low-pressure metamorphic sample localities in the Tunis-El Paso Creeks area (Figures 9 and 10).

Figure 11 is a plot of $\mathrm{Al}^{\mathrm{T}}$ versus $\mathrm{Fe}^{2+} /\left(\mathrm{Fe}^{2+}+\mathrm{Mg}\right)$ for homblendes used for pressure estimates in this study and by Ague and Brimhall [1988b] for the southern half of the Sierra Nevada. The data show a diffuse correlation, as expected from crystal chemical considerations [e.g., Hollister et al., 1987], raising the question of the influence of bulk rock chemistry on $\mathrm{Fe}^{2+} /\left(\mathrm{Fe}^{2+}+\mathrm{Mg}\right)$ and $\mathrm{Al}^{\mathrm{T}}$ in hornblende, and thus on calculated pressures. It is noted, however, that the six high-P Tehachapi samples do not themselves display such a correlation, despite a wide range in $\mathrm{Fe}^{2+} /\left(\mathrm{Fe}^{2+}+\mathrm{Mg}\right)$. Three lines of evidence suggest that a bulk rock effect is not important or, at least, not apparent from the data. First, data from Ague and Brimhall [1988a] on

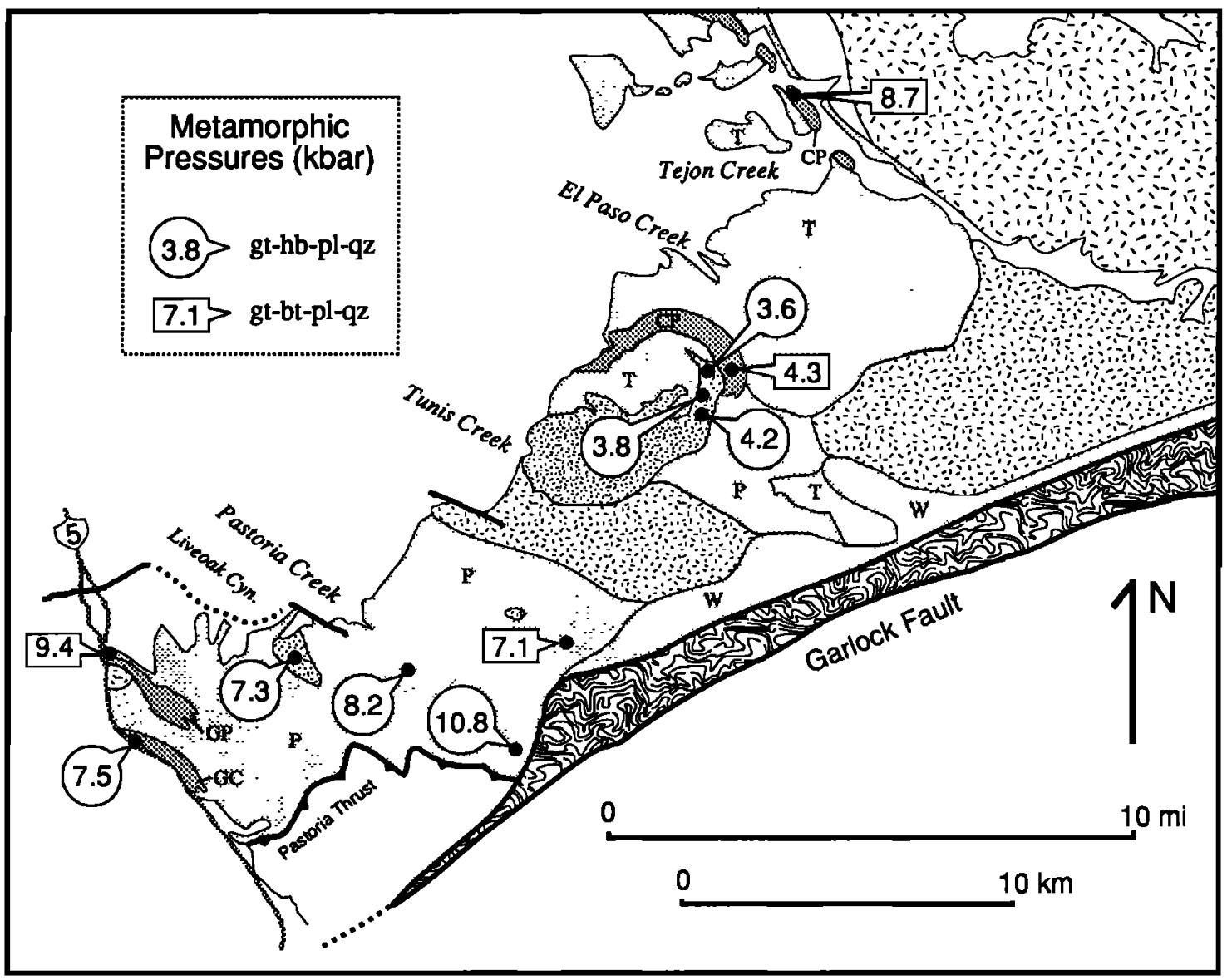

Fig. 9. Map of main study area showing calculated pressures by the gt-hb-pl-qz [Kohn and Spear, 1990] and gt-bt-pl-qz [Hoisch, 1990] methods. Note proximity of high igneous pressures (Figure 10) to the $4 \mathrm{kbar}$ metamorphic zone. For "CORE" and PC107a, only the gt-hb-pl-qz results, which are preferred, are shown. Units as in Figure 2. 


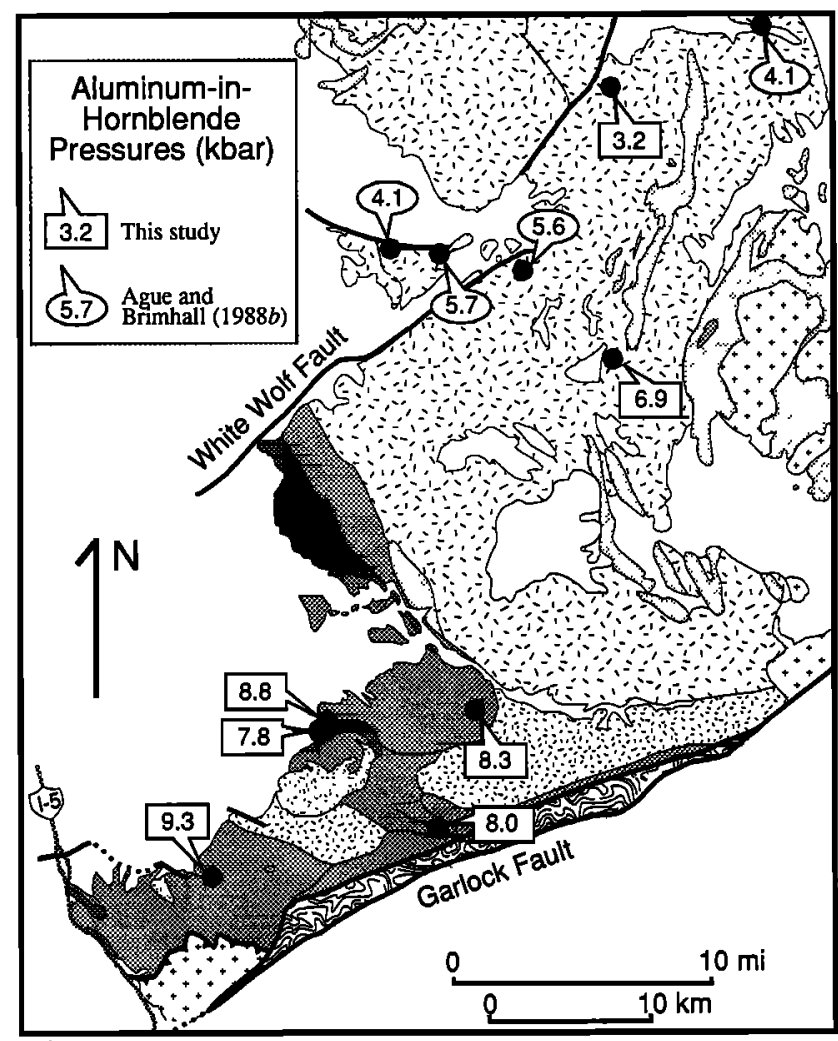

Fig. 10. Map showing distribution of aluminum-in-hornblende igneous pressures (calibration of Hollister et al. [1987]). Included are pressures from Ague and Brimhall [1988b], some of which are from rocks lacking sphene. Units as in Figure 1.

27 Sierra Nevada granitoids used for barometry show no consistent correlation between $\mathrm{Fe}^{2+} /\left(\mathrm{Fe}^{2+}+\mathrm{Mg}\right)$ ratios in hornblendes and bulk rocks. Furthermore, the same data set reveals no correlation at all between bulk-rock $\mathrm{Fe}^{2+} /\left(\mathrm{Fe}^{2+}+\mathrm{Mg}\right)$ and $\mathrm{Al}^{\mathrm{T}}$ in hornblende. Finally, values of $\mathrm{FeO} * /(\mathrm{FeO} *+\mathrm{MgO})$ for intrusive rocks of the study area [Ross, 1989; also D. A. Pickett and J. B. Saleeby, unpublished manuscript, 1991] overlap considerably with values from lower-pressure granitoids from the central batholith [Bateman et al., 1984]. Thus high calculated pressures for the Tehachapi rocks do not appear to reflect any bulk-rock compositional contrast with other rocks of the Sierra Nevada batholith.

In spite of the uncertainties in this barometer [Cosca et al., 1991], two important conclusions may be drawn without reservation from the $\mathrm{Al}$-in-hornblende study. First, the igneous rocks of the main study area crystallized at higher pressures ( $~ 8$ kbar) than any others in the Sierra Nevada batholith (see Ague and Brimhall [1988b] for comparison). Second, crystallization took place at the same deep level throughout the main study area, in contrast to the observation of a zone of low metamorphic pressures.

\section{Summary of P-T Results}

Preferred pressures are shown on the maps of Figures 9 and 10, the pressures and temperatures are plotted in Figure 12, and all results are summarized in Table 7 . The available data show that the igneous rocks of the Tehachapi Mountains crystallized at pressures of $\sim 8 \mathrm{kbar}$. The kyanite occurrence in Grapevine Canyon provides a pressure minimum of $7.6 \mathrm{kbar}$ for that locality (at $690^{\circ} \mathrm{C}$, see above), immune to the uncertainties inherent in the thermobarometry calculations. Metamorphism

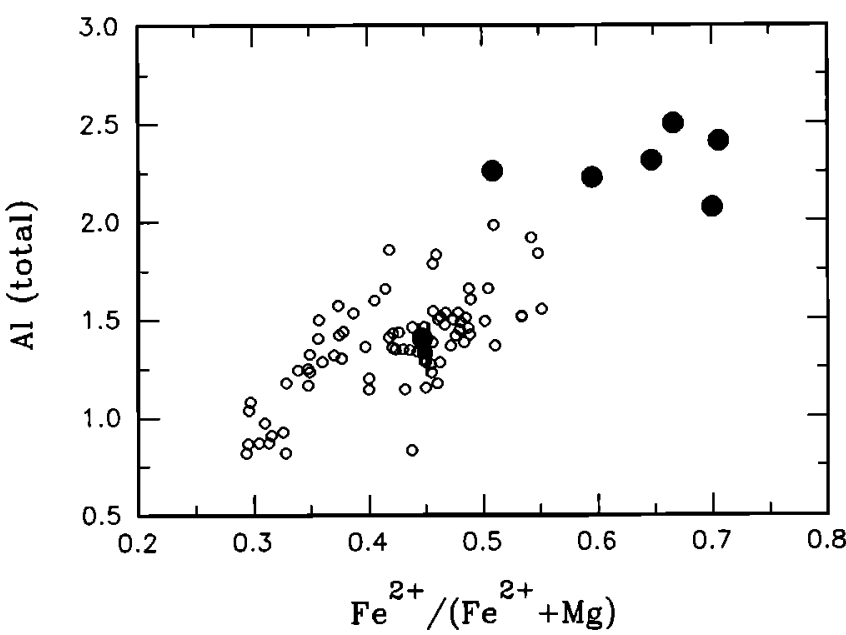

Fig. 11. $\mathrm{AI}^{\mathrm{T}}$ vs. $\mathrm{Fe}^{2+} /\left(\mathrm{Fe}^{2+}+\mathrm{Mg}\right)$ of hornblendes used for igneous barometry in this study (solid circles) and from the southem half of the Sierra Nevada batholith by Ague and Brimhall $[1988 a, b]$ (open circles, 75 samples). Note the overall diffuse correlation but the lack of correlation in the six high-Al samples from this study. Other lines of evidence (see text) do not support a bulk-rock chemical influence on hornblende $\mathrm{Al}^{\mathrm{T}}$ contents for these rocks.

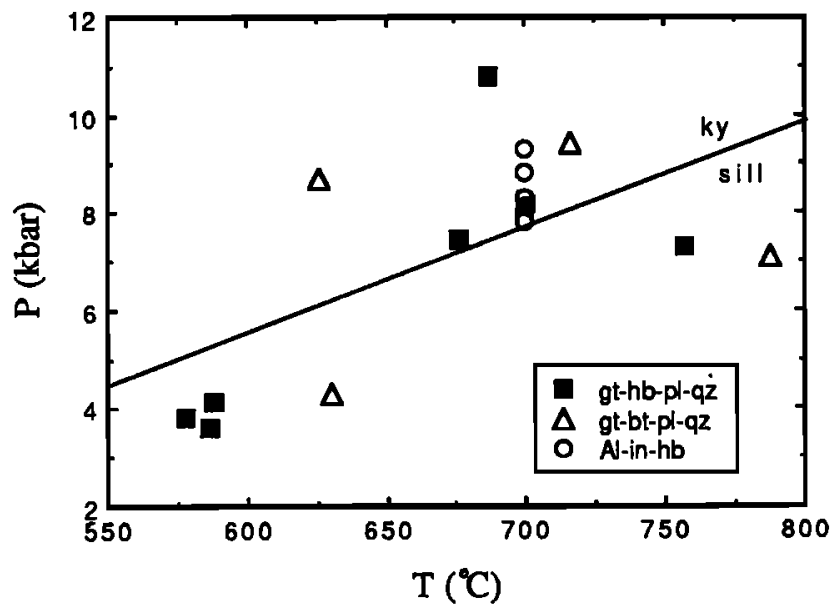

Fig. 12. Summary plot of pressure and temperature calculations based on rim compositions (Table 7). Squares represent gt-hb-pl-qz [Kohn and Spear, 1990], triangles represent gt-bt-pl-qz [Hoisch, 1990], circles represent Al-in-hornblende [Hollister et al., 1987]. Igneous pressures are plotted at $700^{\circ} \mathrm{C}$ for convenience; this temperature was not calculated. Metamorphic pressures are considered to be approximate minimum estimates. Also shown is the kyanitesillimanite reaction boundary [Bohlen et al., 1991]; the Grapevine Peak migmatite lay above this curve at $\mathrm{T} \geq 690^{\circ} \mathrm{C}$.

of framework metasedimentary rocks, as well as subsolidus crystallization and equilibration in the igneous rocks, occurred at 7-8 kbar in most parts of the study area, but there is evidence for considerably lower pressures ( $4 \mathrm{kbar}$ ) between Tunis and $\mathrm{El}$ Paso Creeks. Because of our incomplete understanding of the reaction histories of the rocks, we must consider this apparent low-pressure feature to be a preliminary interpretation in light of its potentially far-reaching implications. Further work is necessary in order to better define the P-T paths of the rocks and to confirm the low-pressure event.

Temperatures do not follow systematic areal patterns, except for garnet-hornblende results, which are $680^{\circ}-760^{\circ} \mathrm{C}$ in the higher-pressure rocks and $\sim 580^{\circ}$ in the lower. Preferred garnetbiotite temperatures are $570^{\circ}-790^{\circ}$ for rim pairs, the large range probably due to reequilibration on cooling, but also perhaps to 
TABLE 7. Summary of Preferred Temperatures, Pressures, and Fluid Compositions

\begin{tabular}{|c|c|c|c|c|}
\hline & Lithology & $T,{ }^{\circ} \mathrm{C}$ & $P$, kbar & $\mathrm{X}_{\mathrm{H}_{2} \mathrm{O}}$ \\
\hline $\begin{array}{l}\text { TC-83* } \\
\text { GC-22* } \\
\text { TC-2a* } \\
\text { GV-1a* } \\
\text { GC-46* } \\
\text { CORE* } \\
\text { PC107a* } \\
\text { GV-2 } \\
80-301^{\dagger} \\
\text { TC-8 } \\
\text { GC-2 } \\
\text { GC } \\
\text { GV-4d } \\
\text { CM650 } \\
\text { CM }\end{array}$ & $\begin{array}{l}\text { metagabbro } \\
\text { metagabbro } \\
\text { metagabbro } \\
\text { metagabbro } \\
\text { metagabbro } \\
\text { metatonalite } \\
\text { metatonalite } \\
\text { metatonalite } \\
\text { metatonalite } \\
\text { paragneiss } \\
\text { paragneiss } \\
\text { paragneiss } \\
\text { calc-silicate }\end{array}$ & $\begin{array}{l}580 \\
590 \\
590 \\
680 \\
760 \\
690 \\
700 \\
720 \\
790 \\
630 \\
630 \\
570\end{array}$ & $\begin{array}{r}3.8 \\
3.6 \\
4.2 \\
7.5 \\
7.3 \\
10.8 \\
8.2 \\
9.4 \\
7.1 \\
4.3 \\
8.7\end{array}$ & $\begin{array}{l}0.01 \\
0.02 \\
0.02 \\
0.05 \\
0.05\end{array}$ \\
\hline $\begin{array}{l}\text { BM149 } 149 \\
\text { CM13b } \\
\text { WR27a } 27 \\
\text { TC- } 12 a^{\S} \\
\text { GC- } 16^{\S} \\
\text { CM } 657^{\S} \\
\text { GC- } 33^{\S}\end{array}$ & $\begin{array}{l}\text { tonalite } \\
\text { granite } \\
\text { tonalite } \\
\text { tonalite } \\
\text { granite } \\
\text { tonalite } \\
\text { granodiorite }\end{array}$ & & $\begin{array}{l}3.2 \\
6.9 \\
8.0 \\
7.8 \\
8.3 \\
8.8 \\
9.3\end{array}$ & \\
\hline
\end{tabular}

*Garnet-hornblende and garnet-hornblende-plagioclase-quartz thermobarometry (Table 6) and garnet-hornblende-plagioclase-quartz$\mathrm{H}_{2} \mathrm{O}$ for $\mathrm{H}_{2} \mathrm{O}$ activity [Ghent, 1988].

${ }^{\dagger}$ Garnet-biotite and garnet-biotite-plagioclase-quartz thermobarometry (Table 7) and garnet-biotite-plagioclase-orthoclase-quartz- $\mathrm{H}_{2} \mathrm{O}$ for $\mathrm{H}_{2} \mathrm{O}$ activity. Metatonalite results are considered less reliable than paragneiss results.

$\stackrel{\ddagger}{\ddagger}$ Scapolite-plagioclase-gamet-quartz- $\mathrm{CO}_{2}$ for $\mathrm{CO}_{2}$ activity [Moecher and Essene, 1985].

${ }^{\S}$ Al-in-hornblende barometry [Hollister et al., 1987]. The Hammarstrom and Zen [1986] calibration gives pressures 0.5-0.7 kbar lower.

overestimates in the metatonalites. Considerations of diffusional modification of garnet compositions suggest that the rocks may have cooled at rates of around $500^{\circ} \mathrm{C} / \mathrm{Ma}$.

Pressures of intrusion are lower for more northern samples of the Bear Valley Springs tonalite, implying that the more gneissic rocks of the main study area may constitute the plutonic substrate of the large Bear Valley Springs batholith.

\section{Estimated Fluid Compositions}

We have calculated $\mathrm{H}_{2} \mathrm{O}$ and $\mathrm{CO}_{2}$ activities for some of the samples utilized for pressure and temperature calculations (Table 7) by writing volatile-present reactions for their assemblages. The reactions were calculated using the program PTX-SYSTEM of Perkins et al. [1986] with the thermodynamic data base of Berman et al. [1985]. We assume only $\mathrm{H}_{2} \mathrm{O}$ and $\mathrm{CO}_{2}$ in the fluid phase, with nonideal mixing as modeled by Kerrick and Jacobs [1981]. Activity models used are Newton et al. [1980] for plagioclase, Hodges and Spear [1982] for garnet, Fuhrman and Lindsley [1988] for alkali feldspar, Oterdoom and Gunter [1983] for scapolite, Ghent [1988] for tremolite in hornblende, and ideal mixing for biotite.

6 tremolite +21 anorthite $=11$ grossular +10 pyrope +27 quartz $+6 \mathrm{H}_{2} \mathrm{O}$ [Ghent, 1988]. We report results using Ghent's coupled substitution tremolite activity model because it always results in higher $\mathrm{X}_{\mathrm{H}_{2} \mathrm{O}}$, meaning our estimates of $\mathrm{X}_{\mathrm{H}_{2} \mathrm{O}}$ (Table 7) are maxima. Taking into account temperature and pressure uncertainties, $\mathrm{X}_{\mathrm{H}_{2} \mathrm{O}}$ in the five metagabbros is limited to $<0.2$. Large uncertainties for the metatonalites (PC107a $=0.05-0.4$; "CORE" = 0.1-1.0) preclude meaningful estimates. Cosca et al. [1991] point out potentially serious sources of error in such
$a_{\mathrm{H} 2} \mathrm{O}$ calculations due to uncertainty in tremolite activity models and $\mathrm{OH}$ site occupancy. Nevertheless, the low $\mathrm{H}_{2} \mathrm{O}$ activities calculated for the metagabbros are not unreasonable considering that garnet appears to grow at the expense of hornblende (Figure 5), resulting in a net dehydration. While it is possible that the low $\mathrm{H}_{2} \mathrm{O}$ activities could result from the absence of fluids, the appearance of garnet in veins, fractures, and specific textural zones and the scattered occurrence suggest that fluids were present and that they in fact provided a kinetic impetus to the garnet-forming, reaction. We therefore tentatively conclude that the appearance of garnet in these rocks resulted from a subsolidus, channelized, nonpervasive influx of $\mathrm{CO}_{2}$-rich fluids. More direct evidence for fluid compositions awaits further study.

3 quartz +2 phlogopite +3 anorthite $=$ grossular $+2 \mathrm{~K}-$ feldspar +2 pyrope $+2 \mathrm{H}_{2} \mathrm{O}$. Application of this equilibrium to paragneiss TC-8 yields $\mathrm{X}_{\mathrm{H} 2 \mathrm{O}}=0.24$, with an uncertainty range of $0.1-0.5$, again suggestive of relatively low $\mathrm{H}_{2} \mathrm{O}$ activities. If we assume again a fluid that is primarily a $\mathrm{CO}_{2}-\mathrm{H}_{2} \mathrm{O}$ mixture we may then calculate $\mathrm{CO}_{2}$ fugacity; the presence of graphite allows us to use the equilibrium $\mathrm{C}+\mathrm{O}_{2}=\mathrm{CO}_{2}$ to calculate $f_{\mathrm{O}_{2}}$ [Edwards and Essene, 1988]. This method estimates quite a low $\log f_{\mathrm{O}_{2}}$ of $-19 \pm \sim 1$ (i.e., near QFM). This evidence for quite reducing conditions is consistent with the qualitative evidence for widespread low $f_{\mathrm{O}_{2}}$ mentioned above.

2 meionite + quartz $=$ grossular +5 anorthite $+2 \mathrm{CO}_{2}$. Moecher and Essene [1985] proposed this equilibrium for calculating $\mathrm{CO}_{2}$ activities in scapolite-bearing calc-silicate rocks. For sample $\mathrm{CM} 650 \mathrm{~b}$, at $780^{\circ} \mathrm{C}$ (scapolite-plagioclase temperature) and $8 \mathrm{kbar}$, calculated $\mathrm{X}_{\mathrm{CO}_{2}}$ is 0.34 ; for lower temperatures, $\mathrm{X}_{\mathrm{CO}_{2}}$ would be even lower. This suggests that this rock experienced fluids more aqueous than did the previously discussed samples. Earlier in this paper, we described another calc-silicate sample which bore evidence for retrograde hydration by aqueous fluids.

In summary, fluid compositions during metamorphism appear to have been variable and were not controlled by a pervasive influx. While garnet-bearing metagabbros show evidence for the action of $\mathrm{H}_{2} \mathrm{O}$-poor fluids, somewhat more aqueous fluids are allowed in the case of paragneiss TC-8, and $\mathrm{H}_{2} \mathrm{O}$-rich fluids are indicated for the calc-silicate rocks.

\section{DisCUSSION}

\section{Physical and Chemical Conditions}

Thermobarometric estimates indicate that the $115-100 \mathrm{Ma}$ intrusive rocks of the Tehachapi Mountains were emplaced at pressures of $\sim 8 \mathrm{kbar}$. This corresponds to depths of $\sim 30 \mathrm{~km}$, making them the deepest-formed exposed rocks known in the Sierra Nevada batholith. Subsolidus metamorphism of these igneous rocks and of framework metasedimentary rocks, some of which may have been related to channelized influx of $\mathrm{CO}_{2-}$ rich fluids, occurred at these same depths and at temperatures of $>630^{\circ} \mathrm{C}$. The lower estimated temperatures most likely do not reflect peak conditions; abundant migmatization and the lack of metamorphic gradients adjacent to intrusive rocks suggest that rocks throughout the crystalline complex reached temperatures in excess of $700^{\circ} \mathrm{C}$. Final cooling of the complex may have occurred quite rapidly $\left(500^{\circ} \mathrm{C} / \mathrm{Ma}\right)$.

Igneous pressures decrease to the north in the tonalite of Bear Valley Springs, through $7 \mathrm{kbar}$ to $5.6 \mathrm{kbar}$ [Ague and Brimhall, $1988 \mathrm{~b}$ ] to $3.2 \mathrm{kbar}$ in the far north. These are supportive of the general view [Sams and Saleeby, 1988] of the more gneissic 
rocks south of Tejon Creek as a substrate to the large, $100 \mathrm{Ma}$ Bear Valley Springs pluton.

The apparent 4-kbar garnet-forming event (Tunis Creek) is superimposed on an area that bears evidence for intrusion at 8 kbar, and high-pressure intrusion and metamorphism are found both to the north and southwest of this zone (Figures 9 and 10). There is no field evidence for major structural breaks bounding this apparent low-pressure zone. Because we must consider the 4 kbar pressures to be minimum estimates (see above), our interpretation of a separate low-pressure event is preliminary. If valid, these pressures imply localized metamorphism after the entire crystalline complex had been uplifted from $\sim 30 \mathrm{~km}$ depth to $\sim 15 \mathrm{~km}$, perhaps due to a channelized influx of $\mathrm{CO}_{2}$ rich fluids. Such fluids are considered by some [e.g., Newton, 1989] to be a fairly common, though not ubiquitous, feature of the lower crust. Overall, calculated fluid compositions are variable, arguing against any large-scale, pervasive fluid influx. In fact, the lack of widespread granulite grade assemblages demonstrates that low $\mathrm{H}_{2} \mathrm{O}$ activity is not a characteristic feature of the complex.

\section{Tectonic Implications}

Uplift. The plutonic rocks of the Tehachapi Mountains were intruded in a dynamic tectonic environment [Sams, 1986; Saleeby et al., 1987; Sams and Saleeby, 1988]. The metamorphism described here occurred both during and after the development of high-temperature deformation fabrics; for example, some of the garnet-bearing veins in the metaigneous rocks cut across the near-solidus fabrics. The garnet-bearing veins and the high-temperature fabrics are in turn locally transposed by lower-temperature, domainal, typically shallowly north-dipping mylonitic fabrics, particularly along and near the north branch of the Garlock fault (Figure 2). The results of this study may place constraints on the relationships between these different events and uplift of the deep-seated Tehachapi rocks. Sharry [1981] suggested that this uplift is related to underthrusting of Rand Schist, which is exposed south of the north branch of the Garlock fault (Figure 2). Seismic reflection work across the range by P. E. Malin et al. (unpublished manuscript, 1992) has revealed a major, shallowly north-dipping reflector which they interpret as representing such a thrust, projecting to the surface along the north branch of the Garlock fault. This thrust may be related to the observed mylonitic deformation near the north branch of the Garlock fault, although the fault itself appears to now represent a more recent, near-vertical reactivation related to the Garlock fault system. If correct, these tectonic relationships are analogous to those common to other localities of RandOrocopia-Pelona-type schist bodies [Haxel and Dillon, 1978].

Sharry [1981] reported mineral compositional data and thermobarometric estimates for samples of the Rand Schist adjacent to the high-grade rocks of the present study area; we have recalculated pressures and temperatures for three of these rocks utilizing the garnet-plagioclase-muscovite-biotite and garnet-plagioclase-muscovite-quartz barometers of Hodges and Crowley [1985], combined with the garnet-biotite thermometer of Hodges and Spear [1982] (the samples were not compositionally compatible with the Hoisch [1990] methods). Pressures lie in the range 8.2-9.7 kbar, while temperatures are $590^{\circ}-680^{\circ} \mathrm{C}$. The Rand Schist was thus metamorphosed at the same deep levels as the Tehachapi complex. Sharry [1981] also reports temperature gradients in the Rand Schist, based on amphibole compositions, suggestive of a temporal link between initial thrusting and metamorphism. This implies that initial thrusting of the Rand Schist beneath the high-grade Tehachapi rocks may have taken place while the latter were still hot $\left(>600^{\circ}\right)$ and deep. Alternatively, the correspondence in pressures across the north branch of the Garlock fault could have resulted from a later coincidental juxtapositioning.

A minimum uplift rate for the Tehachapi Mountains crystalline rocks, calculated on the basis of exposure of the deep $100 \mathrm{Ma}$ rocks at $52 \mathrm{Ma}$ [Nilsen, 1987], is $0.6 \mathrm{~mm} / \mathrm{yr}$. If, however, we accept the preliminary interpretation of a later, low-pressure event, we calculate a much faster uplift rate. Biotite K/Ar ages (summarized by Ross [1989]) from Grapevine Canyon are 86 and $87 \mathrm{Ma}$, while a Bear Valley Springs tonalite sample from $40 \mathrm{~km}$ to the east yields an age of $86 \mathrm{Ma}$. Since the lower-pressure rocks of the Tunis-El Paso Creeks area (4 kbar) record temperatures of $\sim 590^{\circ}$, well above biotite $\mathrm{Ar}$ blocking temperatures, it seems unlikely that the K/Ar ages from $20 \mathrm{~km}$ to the east and west were set while the rocks were still between 30 and $15 \mathrm{~km}$ deep. If uplift from 30 to $<15 \mathrm{~km}$ took place before $87 \mathrm{Ma}$, this implies a relatively rapid uplift rate of $>1.2 \mathrm{~mm} / \mathrm{yr}$. If this uplift rate also applies to the Rand Schist, this is consistent with the work of Jacobson et al. [1988], who summarize arguments for rapid uplift following metamorphism (pre-70 Ma) for other Rand-Orocopia-Pelonatype schist localities.

May [1989] has proposed a model of synplutonic Late Cretaceous tectonism in southern California related to westward transport of a segment of the magmatic arc, now exposed in Salinia, along major low-angle faults. In the context of his model, the higher-temperature, steeply dipping synplutonic deformation in the Tehachapi Mountains could be a manifestation of tectonism on the periphery of this "westward escaping arc segment." Initial underthrusting of the Rand Schist, had it indeed followed soon after Tehachapi magmatism, may also have resulted from these events. Subsequent uplift could then have resulted from isostatic adjustment after major underthrusting of the low-density metasedimentary rocks [Sharry, 1981]. Therefore it is possible that uplift of the highpressure rocks of the Tehachapi Mountains was a manifestation of an extensional event following crustal thickening, and some of the mylonitic features of the range (the kinematics of which lack detailed study) may result from this later event.

Role of low-angle faults. These proposed temporal relations (thrusting and some uplift before $87 \mathrm{Ma}$ ) contrast with those deduced by Silver and Nourse [1986] for low-angle faulting affecting the Rand Schist in the Rand Mountains, about $50 \mathrm{~km}$ east-northeast of our main study area after removing $50 \mathrm{~km}$ of left-lateral offset on the Garlock fault [Ross, 1989]. Silver and Nourse [1986] conclude that low-angle faulting postdates metamorphism of the schist and emplacement of a $79 \mathrm{Ma}$ pluton, and Silver [1986] describes possibly correlative faults in the southern Sierra Nevada, just across a palinspastically restored Garlock Fault from the Rand Mountains. This later date of faulting (post-79 Ma) could only hold for the Tehachapi Mountains if thrusting significantly post-dated high-pressure metamorphism on both sides of the thrust, counter to the apparent contemporaneity of metamorphism and thrusting suggested by Sharry [1981]. Resolution of these differing scenarios for probably correlative tectonic assemblages awaits better age control on faulting and thermal events. Perhaps initial thrusting in the Tehachapis, accompanied by highpressure metamorphism, represents an event separated in time from a later, higher-level reactivation correlative with the 
faulting described by Silver [1983, 1986] and Silver and Nourse [1986]. Such a reactivation is proposed for the Rand Mountains by Postlethwaite and Jacobson [1987] and Nourse and Silver [1986], who describe multiple episodes of faulting with varying shear directions. Reactivation may be responsible for many of the lower-temperature deformational features in the Tehachapi Mountains, including the intense deformation and greenschist-grade retrograde metamorphism of the White Oak diorite gneiss along the north branch of the Garlock fault, cataclasis and mylonitization in the vicinity of the fault, and scattered deformation elsewhere [Sams and Saleeby, 1988].

Conditions favorable for delamination. The Tehachapi Mountains appear to represent a site of major mid-crustal delamination. Geophysical evidence suggests that the range has high seismic velocities at relatively shallow depths and no apparent root [Hearn and Clayton, 1986; also P. E. Malin et al., unpublished manuscript, 1992]. Regardless of the tectonic setting responsible for deformation and uplift of the deepseated rocks, it is clear that at depths of $\sim 30 \mathrm{~km}$, the southern Sierra Nevada batholith was susceptible to disruption. As pointed out above, the average composition of the intrusive rocks is approximately tonalitic with an appreciable proportion of granite; thus quartz is a significant component. Combined with the prolonged high-temperature conditions, lasting at least from $\sim 115 \mathrm{Ma}$ (earlier zircon ages) to almost 87 $\mathrm{Ma}$ (earliest biotite K/Ar ages), this would imply a weak, ductile middle crust susceptible for an extended period of time to ductile deformation and delamination from the deeper crust.

\section{Similar Mid-Cretaceous Deep Batholithic Rocks in Central and Southern California}

Similarities between the southern Sierra Nevada and plutonic and high-grade metamorphic rocks of the Salinian block and in particular between the Tehachapi Mountains and the western Santa Lucia Range (inset in Figure 1) have been discussed in depth [e.g., Page, 1981; Ross, 1984, 1989; Mattinson and James, 1985; Silver and Mattinson, 1986; James and Mattinson, 1988; Pickett and Saleeby, 1991]. These include the presence of orthopyroxene-bearing or "charnockitic" granitoids, upper amphibolite to granulite metamorphic grades, and mid-Cretaceous timing of intrusion and metamorphism. In the southwestern Santa Lucia Range, Hansen and Stuk [1989] estimate metamorphic conditions of 7.5-8.5 kbar at $750^{\circ}-820^{\circ}$. These conditions are similar to those determined here for the Tehachapi Mountains, although in the Santa Lucia range, true granulite-facies assemblages are more common [Compton, 1960]. The deep-seated rocks of the two areas may have followed similar uplift histories: Mattinson [1978] inferred that $104 \mathrm{Ma}$ plutons of the central Santa Lucia Range had remained at $>500^{\circ}$ for $\sim 25 \mathrm{~m}$.y., followed by rapid uplift and cooling. However, some features of the Santa Lucia rocks have closer affinity to more eastern components of the southern Sierra Nevada: marble and feldspathic quartzite compositions are more abundant than in the gneiss complex of the Tehachapi Mountains, mafic intrusive lithologies are less abundant, and initial ${ }^{87} \mathrm{Sr} /{ }^{86} \mathrm{Sr}$ and ${ }^{143} \mathrm{Nd} / 144 \mathrm{Nd}$ ratios are higher and lower, respectively (compare Mattinson [1990] with Saleeby et al. [1987] and Pickett and Saleeby [1989, also unpublished manuscript, 1991]). Therefore it is not possible to draw a direct correlation between these two areas of high-pressure batholithic rocks; it is possible, however, that they represent exposures of similar depths from differing east-west positions within the regional Cretaceous batholithic belt.

The San Gabriel Mountains of southern California (inset in Figure 1) also bear evidence for exposure of deep-seated (20-30 km) Cretaceous plutonic rocks, albeit in a quite different prebatholithic framework [Barth, 1990]. These include rocks of the Cucamonga terrane of the southeastern San Gabriel Mountains, which contrast compositionally, isotopically, and mineralogically with the Tehachapi rocks but have similar metamorphic histories [May and Walker, 1989; Barth and May, 1992; Barth et al., 1992]. The pressure-temperature-time sequence of Barth and May [1992] (peak conditions at $8 \mathrm{kbar}$ at $105 \mathrm{Ma}$, followed by rapid decompression to $5 \mathrm{kbar}$ at $85 \mathrm{Ma}$ ) is strikingly similar to our provisional Tehachapi history. Of course, any actual correlation of events in the two areas is made more difficult by the fact of their wide separation $(\sim 350 \mathrm{~km})$ prior to San Andreas fault offset.

\section{Implications for Batholith Structure}

Character of the deeper batholith. The first-order interpretation of the data presented in this paper is that the Sierra Nevada batholith extended to great depth, with voluminous magmas crystallizing at depths of at least $30 \mathrm{~km}$. In gross compositional and isotopic terms [Sams, 1986; Saleeby et al., 1987; Sams and Saleeby, 1988; Pickett and Saleeby, 1989, also unpublished manuscripts] these magmas are not markedly different from those intruded at higher levels in the batholith. The average composition is roughly tonalitic to mafic tonalitic and the various lithologies, including the hypersthene tonalites, quartz diorites, and cumulate gabbros, have affinities with those along the western margin of the batholith to the north [Saleeby and Sharp, 1980a,b], where shallower conditions are inferred [Ague and Brimhall, 1988b; Saleeby, 1990; Clemens Knott et al., 19901; thus the compositional character of the Tehachapi intrusive rocks may not necessarily reflect some intrinsic feature of the deeper reaches of a batholith. While it is true that there is an appreciable amount of gabbroic and dioritic rock at small and large scales, this component has perhaps been overemphasized [Hamilton, 1988; Ross, 1989] at the expense of tonalitic to granitic lithologies.

However, in order to make a valid comparison between the Tehachapi rocks and higher-level Sierran intrusives, it is helpful to place the Tehachapi magmas in the context of the well-known west-to-east isotopic and petrologic variations in the main part of the batholith [e.g., Kistler and Peterman, 1978]. Initial ${ }^{87} \mathrm{Sr} / 86 \mathrm{Sr}$ and $\varepsilon_{\mathrm{Nd}}$ for the intrusive rocks of the main study area [Saleeby et al., 1987; Pickett and Saleeby, 1989, also unpublished manuscript, 1992] range from 0.7042 to 0.7054 and +2.6 to -0.8 , respectively, placing them within the isotopic range observed for west-central intrusives of the batholith (west of the 0.706 isopleth), where tonalitic compositions prevail [Bateman et al., 1984; Saleeby et al., 1986, and references therein]. In contrast, the gabbroic to tonalitic rocks of the westernmost batholith have lower ${ }^{87} \mathrm{Sr} /{ }^{86} \mathrm{Sr}$ and higher $\varepsilon_{\mathrm{Nd}}$ [Clemens Knott et al., 1990] than those in the Tehachapi Mountains. The isotopic affinity between the Tehachapi magmatic rocks and the west-central tonalitic belt also applies to the metamorphic frameworks of the intrusive rocks: in these two areas, the metamorphic pendants consist of Kings sequence thick continental margin sedimentary assemblages with unknown basement [Saleeby et al., 1978, 1987]. In contrast, the westernmost gabbroic to 
tonalitic belt intrudes the Kings-Kaweah ophiolite belt with only a thin veneer of western distal Kings sequence strata. However, chemical data from the west-central tonalitic belt [Bateman et al., 1984] show this belt, in contrast to the Tehachapi igneous suites, to be more homogeneous and somewhat less mafic. Placed, then, in a proper context within the Sierra Nevada batholith, compositions of the intrusive rocks of the Tehachapi Mountains appear to reflect a deeper batholith which is more heterogeneous and somewhat more mafic than at higher levels.

The $\mathrm{Sr}, \mathrm{Nd}, \mathrm{O}$, and zircon $\mathrm{U} / \mathrm{Pb}$ isotopic systematics of the Tehachapi rocks [Saleeby et al., 1987; Pickett and Saleeby, 1989, also unpublished manuscript, 1992] show evidence for mixing of depleted mantle-derived magmas with appreciable components of old continental, probably metasedimentary, material. The rocks of the Tehachapi Mountains thus provide evidence for major reconstitution of the continental margin crust to great depths $(>30 \mathrm{~km})$ during batholith construction. This further implies that the preintrusive crust of the Sierra Nevada was already at least $30 \mathrm{~km}$ thick due to earlier episodes of tectonic thickening.

Comparison with Sierra Nevada xenoliths. Samples of the crust and mantle beneath the central Sierra Nevada batholith are found as xenoliths in Tertiary volcanic rocks. A diverse suite from Chinese Peak [Dodge et al., 1986] does include gabbros and "mafic granulites," with some bulk chemical similarities to gabbros and diorites of the Tehachapi Mountains. However, a major distinction between these xenoliths and Tehachapi rocks is the paucity in the former of homblende, garnet, and tonalitic to granitic lithologies. Xenoliths from Big Creek [Domenick et al., 1983; Dodge et al., 1988] have more in common with rocks of the Tehachapi Mountains, including numerous examples of plagioclase \pm hornblende \pm pyroxene \pm garnet rocks similar in mineralogy and texture to more mafic Tehachapi lithologies. However, correlatives of the common tonalite to granite gneisses of the Tehachapi Mountains are few. In summary, direct correlation between these Sierran xenoliths and the deep-batholith rocks of the Tehachapi Mountains is not possible. The predominance of more mafic lithologies in the xenolith suites may reflect batholithic sources at depths even greater than those now exposed in the Tehachapi Mountains [Saleeby et al., 1986].

Deep rocks of other Cordilleran batholiths. Zen [1988] summarizes information on deep-seated, epidote-bearing calcalkaline plutons from the Idaho and Coast Batholiths of the northern Cordillera. These rocks are inferred to have crystallized at pressures of 6-8 kbar with average geothermal gradients of $\sim 25^{\circ}-30^{\circ} \mathrm{C} / \mathrm{km}$, conditions similar to those in the Tehachapi Mountains. Lithologies, as in the Tehachapi Mountains, are dominantly quartz diorite to tonalite to granodiorite, and metamorphic framework rocks have supracrustal protoliths; gneissic foliation is not a ubiquitous feature. Relatively rapid average uplift rates $(0.2-0.6 \mathrm{~mm} / \mathrm{yr})$ are responsible for exposure of these rocks, but apparently synplutonic deformation as observed in the Tehachapis is not a necessary component of the structural history. Zen [1988] emphasizes the necessity of thick $(50-60 \mathrm{~km})$ sialic crust for production of these deep plutons. Along with the results of this study, these occurrences show that, at least down to $30 \mathrm{~km}$ depths, Cordilleran batholiths and their framework rocks retain the basic lithologic character of the abundantly exposed higher levels of the batholiths.

\section{SUMMARY AND CONCLUSIONS}

1. The 115-100 $\mathrm{Ma}$ intrusive rocks of the Tehachapi Mountains were emplaced at depths of $\sim 25-30 \mathrm{~km}$, making them the deepest exposed known members of the Cretaceous Sierra Nevada batholith. These rocks represent the culmination of a regional-scale, oblique exposed section through the batholith in its southem half [Saleeby, 1990].

2. Localized subsolidus metamorphism of these intrusive rocks, as well as metamorphism of framework sedimentary rocks, occurred at these same pressures (i.e., $\sim 8 \mathrm{kbar}$ ) at $\geq 700^{\circ} \mathrm{C}$. Our preliminary interpretation of low- $P$ results from the area between Tunis and El Paso Creeks implies a second, local metamorphic event after an apparent $\sim 15 \mathrm{~km}$ of uplift at $\sim 600^{\circ}$. Garnet-forming reactions in the metaigneous rocks formed by the action of nonpervasive, channelized flow of generally $\mathrm{CO}_{2}$-rich fluids. More detailed metamorphic and geochronologic study is required to fully elucidate the pressuretemperature-time sequence of the complex. The crystalline rocks of the Tehachapi Mountains do not properly constitute a "granulite" terrane, as most orthopyroxene occurrences are of igneous origin.

3. Assuming that our interpretation of the 4-kbar event is correct, uplift from 30 to $15 \mathrm{~km}$ deep followed soon after intrusion and 8-kbar metamorphism and was probably completed by $\sim 87 \mathrm{Ma}$; this implies a minimum uplift rate of 1.2 $\mathrm{mm} / \mathrm{yr}$. Uplift to surface conditions was completed by $22 \mathrm{Ma}$. Initial uplift may have followed underthrusting of Rand Schist from what is now the southeast. Predominantly low-angle ductile deformation fabrics formed in response to underthrusting and to later reactivation in the vicinity of the thrust.

4. These pressure-temperature conditions and inferred uplift history resemble those in otherwise noncorrelative metamorphic and plutonic rocks of the Santa Lucia Range, Salinia, and of the southeastern San Gabriel Mountains. This similarity may reflect major, regional-scale tectonic events.

5. As compared with higher levels of similar isotopic character, the deep Sierra Nevada batholith, as exposed in the Tehachapi Mountains, is lithologically more heterogeneous and somewhat more mafic in average composition. Cumulate rocks are common, though not predominant, and metasedimentary rocks are typically migmatitic. The intrusive rocks at this deep level show the same isotopic evidence [D. A. Pickett and J. B. Saleeby, unpublished manuscript, 1992] for hybridization between mantle and continental crustal sources that is observed throughout the batholith.

6. At $30 \mathrm{~km}$ depths, the Sierra Nevada batholith is still rich in quartz. This allows for a wide temperature range under which conditions are favorable for ductile deformation and possible delamination of the young batholithic crust. Thus the middle to deep batholith may prove to be a common site of major tectonic disruption and transport.

Acknowledgments. The authors benefitted from discussions with $\mathrm{D}$. Sams, L. Silver, D. May, J. Y. Bradshaw, C. Gallup, M. Kohn, P. Malin, and J. Sharry, who also graciously provided a sample chip. Thanks are due $D$. May for providing unpublished manuscripts. Thorough reviews by Lawford Anderson, Frank Spear, and Tom Brocher greatly improved the paper. P. Carpenter offered instruction in electron microprobe analysis and data manipulation, and $M$. Fahnestock helped with the figures and tables. We thank the Tejon Ranch Company for access to most of the study area. This research was supported by National Science Foundation grants EAR-8904063 and EAR-9105692. Division of Geological and Planetary Sciences contribution no. 5220 . 


\section{REFERENCES}

Ague, J. J., and G. H. Brimhall, Regional variations in bulk chemistry, mineralogy, and the compositions of mafic and accessory minerals in the batholiths of California, Geol. Soc. Am. Bull., 100, 891-911, $1988 a$.

Ague, J. J., and G. H. Brimhall, Magmatic arc asymmetry and distribution of anomalous plutonic belts in the batholiths of Califomia: Effects of assimilation, crustal thickness, and depth of crystallization, Geol. Soc. Am. Bull., 100, 912-927, 1988 b.

Anderson, J. L., Core complexes of the Mojave-Sonoran Desert: conditions of plutonism, mylonitization, and decompression, in Metamorphism and Crustal Evolution of the Western United States (Rubey vol. VII), edited by W. G. Ernst, pp. 502-525, Prentice-Hall, Englewood Cliffs, N. J., 1988.

Armstrong, J. T., Quantitative analysis of silicate and oxide materials: Comparison of Monte Carlo, ZAF, and $\phi(\rho z)$ procedures, in Microbeam Analysis - 1988, edited by D. E. Newbury, pp. 239-246, San Francisco Press, San Francisco, Calif., 1988.

Barth, A. P., Mid-crustal emplacement of Mesozoic plutons, San Gabriel Mountains, California, and implications for the geologic history of the San Gabriel terrane, Mem. Geol. Soc. Am., I74, 33$45,1990$.

Barth, A. P., and D. J. May, Mineralogy and pressure-temperature-time path of Cretaceous granulite gneisses, southeastern San Gabriel Mountains, southern Califomia, J. Metamorph. Geol. 10, 529-544, 1992.

Barth, A. P., J. L. Wooden, and D. J. May, Small scale heterogeneity of Phanerozoic lower crust: Evidence from isotopic and geochemical systematics of mid-Cretaceous granulite gneisses, San Gabriel Mountains, southem California, Contrib. Mineral. Petrol., 109, 394407, 1992.

Bateman, P. C., and J. P. Eaton, Sierra Nevada batholith, Science, 158, $1407-1417,1967$.

Bateman, P. C., F. C. W. Dodge, and P. E. Bruggman, Major oxide analyses, CIPW norms, modes, and bulk specific gravities of plutonic rocks from the Mariposa $1^{\circ} \times 2^{\circ}$ sheet, central Sierra Nevada, California, U.S. Geol. Surv. Open File Rep. 84-162, 50 pp., 1984.

Berman, R. G., T. H. Brown, and H. J. Greenwood, An internally consistent thermodynamic data base for minerals in the system $\mathrm{Na}_{2} \mathrm{O}$ $\mathrm{K}_{2} \mathrm{O}-\mathrm{CaO}-\mathrm{MgO}-\mathrm{FeO}-\mathrm{Fe}_{2} \mathrm{O}_{3}-\mathrm{Al}_{2} \mathrm{O}_{3}-\mathrm{SiO}_{2}-\mathrm{TiO}_{2}-\mathrm{H}_{2} \mathrm{O}-\mathrm{CO}_{2}, A E C$ Tech. Rep. 377, 62 pp., Atomic Energy of Canada Lid., Pinawa, Manitoba, Canada, 1985.

Bohlen, S. R., A. Montana, and D. M. Kerrick, Precise determinations of the equilibria kyanite $\Leftrightarrow$ sillimanite and kyanite $\Leftrightarrow$ andalusite and a revised triple point for $\mathrm{Al}_{2} \mathrm{SiO}_{5}$ polymorphs, Am. Mineral., 76, 677680, 1991.

Chipera, S. J., and D. Perkins, Evaluation of biotite-garnet geothermometers: Application to the English River subprovince, Ontario, Contrib. Mineral. Petrol., 98, 40-48, 1988.

Clemens Knott, D., J. B. Saleeby, H. P. Taylor, Jr., and B. W. Chappell, Petrology of the Early Cretaceous Sierra Nevada batholith: The Stokes Mountain region, CA, Eos Trans. AGU, 71, 1576, 1990.

Compton, R. R., Charnockitic rocks of Santa Lucia Range, California, Am. J. Sci., 258, 609-636, 1960.

Cosca, M. A., E. J. Essene, and J. R. Bowman, Complete chemical analyses of metamorphic hornblendes: Implications for normalizations, calculated $\mathrm{H}_{2} \mathrm{O}$ activities, and thermobarometry, Contrib. Mineral. Petrol., 108, 472-484, 1991.

Crowell, J. C., The San Andreas fault zone from the Temblor Mountains to Antelope Valley, southern California, in Guidebook, 1964, AAPG Pacific Section, SEPM Pacific Section, and San Joaquin Geol. Soc., pp. 7-39, San Joaquin Geological Society, Bakersfield, Calif., 1964.

Dodge, F. C. W., L. C. Calk, and R. W. Kistler, Lower crustal xenoliths, Chinese Peak lava flow, central Sierra Nevada, J. Petrol., 27, 1277-1304, 1986.

Dodge, F. C. W., J. P. Lockwood, and L. C. Calk, Fragments of the mantle and crust from beneath the Sierra Nevada batholith: Xenoliths in a volcanic pipe near Big Creek, California, Geol. Soc. Am. Bull., 100, 938-947, 1988.

Domenick, M. A., R. W. Kistler, F. C. W. Dodge, and M. Tatsumoto, $\mathrm{Nd}$ and $\mathrm{Sr}$ isotopic study of crustal and mantle inclusions from the Sierra Nevada and implications for batholith petrogenesis, Geol. Soc. Am. Bull., 94, 713-719, 1983.

Edwards, R. L., and Essene, E. J., Pressure, temperature, and C-O-H fluid fugacities across the amphibolite-granulite transition, northwest Adirondack Mountains, New York, J. Petrol., 29, 39-72, 1988.
Ferry, J. M., and F. S. Spear, Experimental calibration of the partitioning of $\mathrm{Fe}$ and $\mathrm{Mg}$ between biotite and garnet, Contrib. Mineral. Petrol., 66, 113-117, 1978.

Florence, F. P., and F. S. Spear, Effects of diffusional modification of garnet growth zoning on P-T path calculations, Contrib. Mineral. Petrol., 107, 487-500, 1991.

Fuhrman, M. L., and D. H. Lindsley, Ternary-feldspar modeling and thermometry, Am. Mineral., 73, 201-215, 1988.

Ghent, E. D., Tremolite and $\mathrm{H}_{2} \mathrm{O}$ activity attending metamorphism of hornblende-plagioclase-garnet assemblages, Contrib. Mineral. Petrol., 98, 163-168, 1988.

Goldsmith, J. R., and R. C. Newton, Scapolite-plagioclase stability relations at high pressures and temperatures in the system $\mathrm{NaAlSi}_{3} \mathrm{O}_{8}$ $\mathrm{CaAl}_{2} \mathrm{Si}_{2} \mathrm{O}_{8}-\mathrm{CaCO}_{3}-\mathrm{CaSO}_{4}$, Am. Mineral., 62, 1063-1081, 1977.

Goodman, E. D., and P. E. Malin, Evolution of the southern San Joaquin Basin and mid-Tertiary transitional tectonics, central California, Tectonics, 11, 478-498, 1992.

Graham, C. M., and R. Powell, A garnet-homblende geothermometer: Calibration, testing, and application to the Pelona Schist, southern California, J. Metamorph. Geol., 2, 13-31, 1984.

Hamilton, W., Tectonic setting and variations with depth of some Cretaceous and Cenozoic structural and magmatic systems of the western United States, in Metamorphism and Crustal Evolution of the Western United States (Rubey vol. VII), edited by W. G. Ernst, pp. 1-40, Prentice-Hall, Englewood Cliffs, N. J., 1988.

Hamilton, W., and W. B. Myers, The nature of batholiths, U.S. Geol. Surv. Prof. Pap. 554-C, 30 pp., 1967.

Hammarstrom, J. M., and E-an Zen, Aluminum in hornblende: An empirical igneous geobarometer, Am. Mineral., 71, 1297-1313, 1986.

Hansen, E. C., and M. A. Stuk, Devolatilization reactions in the amphibolite to granulite facies transitional terrane around Cone Peak, Santa Lucia Range, California (abstract), Geol. Soc. Am. Abstr. Programs, 21, A277, 1989.

Haxel, G., and J. Dillon, The Pelona-Orocopia Schist and VincentChocolate Mountain thrust system, southern California, in Mesozoic Paleogeography of the Western United States: Pacific Coast Paleogeography Symposium 2, edited by D. G. Howell and K. A. McDougall, pp. 453-469, Pacific Section, Society of Economic Paleontologists and Mineralogists, Los Angeles, Calif., 1978.

Hearn, T. M., and R. W. Clayton, Lateral velocity variations in southern California, Part I: Results from the upper crust from $\mathrm{Pg}$ waves, Bull. Seismol. Soc. Am., 76, 495-509, 1986.

Hodges, K. V., and P. D. Crowley, Error estimation and empirical geothermobarometry for pelitic systems, Am. Mineral., 70, 702$709,1985$.

Hodges, K. V., and F. S. Spear, Geothermometry, geobarometry and the $\mathrm{Al}_{2} \mathrm{SiO}_{5}$ triple point at Mt. Moosilauke, New Hampshire, Am. Mineral., 67, 1118-1134, 1982.

Hoisch, T. D., Empirical calibration of six geobarometers for the mineral assemblage quartz + muscovite + biotite + plagioclase + garnet, Contrib. Mineral. Petrol., 104, 225-234, 1990.

Hollister, L. S., G. C. Grissom, E. K. Peters, H.H. Stowell, and V.B. Sisson, Confirmation of the empirical correlation of $\mathrm{Al}$ in hornblende with pressure of solidification of calc-alkaline plutons, Am. Mineral., 72, 231-239, 1987.

Jacobson, C. E., M. R. Dawson, and C. E. Postlethwaite, Structure, metamorphism, and tectonic significance of the Pelona, Orocopia, and Rand Schists, southern California, in Metamorphism and Crustal Evolution of the Western United States (Rubey vol. VII), edited by W. G. Ernst, pp. 976-997, Prentice-Hall, Englewood Cliffs, N. J., 1988.

James, E. W., and J. M. Mattinson, Metamorphic history of the Salinian block: An isotopic reconnaissance, in Metamorphism and Crustal Evolution of the Western United States (Rubey vol. VII), edited by W. G. Ernst, pp. 938-952, Prentice-Hall, Englewood Cliffs, N. J., 1988.

Kanter, L. R., and M. O. McWilliams, Rotation of the southernmost Sierra Nevada, California, J. Geophys. Res., 87, 3819-3830, 1982.

Kerrick, D. M., and G. K. Jacobs, A modified Redlich-Kwong equation for $\mathrm{H}_{2} \mathrm{O}, \mathrm{CO}_{2}$, and $\mathrm{H}_{2} \mathrm{O}-\mathrm{CO}_{2}$ mixtures at elevated pressures and temperatures, Am. J. Sci., 281, 735-767, 1981.

Kistler, R. W., and Z. E. Peterman, Reconstruction of crustal blocks of California on the basis of initial strontium isotopic compositions of Mesozoic granitic rocks, U.S. Geol. Surv. Prof. Pap. 1071, 17 pp., 1978.

Kohn, M. J., and F. S. Spear, Two new geobarometers for garnet 
amphibolites, with applications to southeastern Vermont, $A m$ Mineral., 75, 89-96, 1990.

Leake, B. E., Nomenclature of amphiboles, Am. Mineral., 63, 10231052,1978 .

Mattinson, J. M., Age, origin, and thermal histories of some plutonic rocks from the Salinian block of California, Contrib. Mineral. Petrol., 67, 233-245, 1978.

Mattinson, J. M., Petrogenesis and evolution of the Salinian magmatic arc, Mem. Geol. Soc. Am., 174, 237-250, 1990.

Mattinson, J. M., and E. W. James, Salinian block U/Pb age and isotopic variations: Implications for origin and emplacement of the Salinian terrane, in Tectonostratigraphic Terranes of the CircumPacific Region, edited by D. G. Howell, pp. 215-226, Circum-Pacific Council for Energy and Mineral Resources, Houston, Texas, 1985.

May, D. J., Late Cretaceous intra-arc thrusting in southern California, Tectonics, 8, 1159-1173, 1989.

May, D. J., and N. W. Walker, Late Cretaceous juxtaposition of metamorphic terranes in the southeastern San Gabriel Mountains, Califormia, Geol. Soc. Am. Bull., 101, 1246-1267, 1989.

McWilliams, M. O., and Y. Li, Tectonic oroclinal bending of the southern Sierra Nevada batholith, Science, 230, 172-175, 1985.

Moecher, D. P., and E. J. Essene, Scapolite as a potential sensor of fluid composition in calc-silicates and granulites (abstract), Geol. Soc. Am. Abstr. Programs, 17, 666, 1985.

Newton, R. C., Metamorphic fluids in the deep crust, Ann. Rev. Earth Planet. Sci., 17, 385-412, 1989.

Newton, R. C., T. V. Charlu, and O. J. Kleppa, Thermochemistry of the high structural state plagioclases, Geochim. Cosmochim. Acta, 44, 933-941, 1980.

Nilsen, T. H., Stratigraphy and sedimentology of the Eocene Tejon Formation, western Tehachapi Mountains and San Emigdio Mountains, California, U.S. Geol. Surv. Prof. Pap. 1268, 110 pp., 1987.

Nourse, J. A., and L. T. Silver, Structural and kinematic evolution of sheared rocks in the Rand "thrust" complex, northwest Mojave Desert, California, Geol. Soc. Am. Abstr. Programs, 18, 165, 1986.

Oterdoom, W. H., and W. D. Gunter, Activity models for plagioclase and $\mathrm{CO}_{3}$-scapolites: An analysis of field and laboratory data, Am. J. Sci., 283-A, 255-282, 1983.

Page, B. M., The southern Coast Ranges, in The Geotectonic Development of California (Rubey vol. I), edited by W. G. Ernst, pp. 329-417, Prentice-Hall, Englewood Cliffs, N. J., 1981.

Pakiser, L. C., and J. N. Brune, Seismic models of the root of the Sierra Nevada, Science, 210, 1088-1094, 1980.

Perkins, E. H., T. H. Brown, and R. G. Berman, PTX-SYSTEM: Three programs for calculation of pressure-temperature-composition phase diagrams, Comput. Geosci., 12, 749-755, 1986.

Pickett, D. A., and J. B. Saleeby, Petrogenetic and isotopic studies of mid-crustal batholithic rocks of the Tehachapi Mountains, Sierra Nevada, California (abstract), Geol. Soc. Am. Abstr. Programs, 21 , A197, 1989.

Pickett, D. A., and J. B. Saleeby, The Cretaceous gneissic rocks of the Tehachapi Mountains, southern Sierra Nevada batholith correlatives of Salinia? (abstract), Geol. Soc. Am. Abstr. Programs, $23,89,1991$.

Plescia, J. B., and G. J. Calderone, Paleomagnetic constraints on the timing of rotation of the Tehachapi Mountains, California (abstract), Geol. Soc. Am. Abstr. Programs, 18, 171, 1986.

Postlethwaite, C. E., and C. E. Jacobson, Early history and reactivation of the Rand thrust, southern California, J. Struct. Geol. 9, 195-205, 1987.

Ross, D. C., Possible correlations of basement rocks across the San Andreas, San Gregorio-Hosgri, and Rinconada-Reliz-King City faults, California, U.S. Geol. Surv. Prof. Pap. 1317, 37 pp., 1984.

Ross, D. C., Mafic gneissic complex (batholithic root?) in the southernmost Sierra Nevada, California, Geology, 13, 288-291, 1985.

Ross, D. C., The metamorphic and plutonic rocks of the southernmost Sierra Nevada, California, and their tectonic framework, U.S. Geol. Surv. Prof. Pap. 1381, 159 pp., 1989.

Saleeby, J. B., Progress in tectonic and petrogenetic studies in an exposed cross-section of young $(\sim 100 \mathrm{Ma})$ continental crust southern Sierra Nevada, California, in Exposed Cross Sections of the Continental Crust, edited by M. H. Salisbury, pp. 137-158, D. Reidel, Norwell, Mass., 1990.

Saleeby, J. B., and W. D. Sharp, Chronology of the structural and petrologic development of the southwest Sierra Nevada foothills, California, Geol. Soc. Am. Bull., 91, Part I, 317-320, 1980a.

Saleeby, J. B., and W. D. Sharp, Chronology of the structural and petrologic development of the southwest Sierra Nevada foothills, California, Geol. Soc. Am. Bull., 91, Part II, 1416-1535, 1980 b.

Saleeby, J. B., S. E. Goodin, W. D. Sharp, and C. J. Busby, Early Mesozoic paleotectonic-paleogeographic reconstruction of the southern Sierra Nevada region, in Mesozoic Paleogeography of the Western United States: Pacific Coast Paleogeography Symposium 2, edited by D.G. Howell and K.A. McDougall, pp. 311-336, Pacific Section, Society of Economic Paleontologists and Mineralogists, Los Angeles, Calif., 1978.

Saleeby, J. B., and others, Continent-Ocean Transect: Corridor C2 Central California Offshore to the Colorado Plateau, Geol. Soc. Am. Centen. Continent-Ocean Transect \#10, 63 pp., 1986.

Saleeby, J. B., D. B. Sams, and R. W. Kistler, Geochronology and geochemistry of crystalline rocks of the southernmost Sierra Nevada, California, J. Geophys. Res., 92, 10,443-10,466, 1987.

Sams, D. B., U/Pb zircon geochronology, petrology, and structural geology of the crystalline rocks of the southernmost Sierra Nevada and Tehachapi Mountains, Kern County, California, Ph.D. thesis, 315 pp., California Institute of Technology, Pasadena, California, 1986.

Sams, D. B., and J. B. Saleeby, Geology and petrotectonic significance of crystalline rocks of the southernmost Sierra Nevada, California in Metamorphism and Crustal Evolution of the Western United States (Rubey vol. VII), edited by W. G. Ernst, pp. 865-893, Prentice-Hall, Englewood Cliffs, N. J., 1988.

Schürmann, H. M. E., Granatführender Diorit aus der Sierra Nevada, Kalifornien [Garnet-bearing diorite from the Sierra Nevada, California], Neues Jahrb. für Mineral. Geol. Paläontol., 74, Part A, 225-250, 1938.

Selverstone, J., and C. P. Chamberlain, Apparent isobaric cooling paths from granulites: Two counterexamples from British Columbia and New Hampshire, Geology, 18, 307-310, 1990.

Sharry, J., The geology of the western Tehachapi Mountains, California, Ph.D. thesis, 215 pp., Massachusetts Institute of Technology, Cambridge, Mass., 1981.

Silver, L. T., Paleogene overthrusting in the tectonic evolution of the Transverse Ranges, Mojave and Salinian regions, California (abstract), Geol. Soc. Am. Abstr. Programs, 15, 438, 1983.

Silver, L. T., Evidence for Paleogene low-angle detachment of the southern Sierra Nevada (abstract), Geol. Soc. Am. Abstr. Programs, $18,750,1986$.

Silver, L. T., and J. M. Mattinson, "Orphan Salinia" has a home, Eos Trans. AGU. 67, 1215, 1986

Silver, L. T., and J. A. Nourse, The Rand Mountains "thrust" complex in comparison with the Vincent thrust-Pelona Schist relationship, southem California (abstract), Geol. Soc. Am. Abstr. Programs, 18, $185,1986$.

Spear, F. S., and K. L. Kimball, RECAMP - A FORTRAN IV program for estimating $\mathrm{Fe}^{3+}$ contents in amphiboles, Comput. Geosci., 10, 317$325,1984$.

Vielzeuf, D., and J. R. Holloway, Experimental determination of the fluid-absent melting relations in the pelitic system: consequences for crustal differentiation, Contrib. Mineral. Petrol. 98 , 257-276, 1988.

Warren, R. G., B. J. Hensen, and R. J. Ryburn, Wollastonite and scapolite in Precambrian calc-silicate granulites from Australia and Antarctica, J. Metamorph. Geol., 5, 213-223, 1987.

Zen, E-an, Tectonic significance of high-pressure plutonic rocks in the western Cordillera of North America, in Metamorphism and Crustal Evolution of the Western United States (Rubey vol. VII), edited by W. G. Ernst, pp. 41-67, Prentice-Hall, Englewood Cliffs, N. J., 1988.

Zen, E-an, Plumbing the depths of batholiths, Am. J. Sci., 289, 1137. $1157,1989$.

D. A. Pickett, Isotope Sciences, MS J514, Los Alamos National Laboratory, Los Alamos, NM 87545.

J. B. Saleeby, Division of Geological and Planetary Sciences, 17025, California Institute of Technology, Pasadena, CA 91125.

(Received December 15, 1990;

revised July 31,1992 ;

accepted July 31, 1992.) 